TRABAJO DE GRADO

MAESTRÍA EN DERECHO CONTRACTUAL PÚBLICO Y PRIVADO

\title{
ANÁLISIS DE LA CONTRATACIÓN EN EL MINISTERIO DE EDUCACIÓN CON ORGANISMOS DE COOPERACIÓN INTERNACIONAL: UNA PROPUESTA PARA SU MEJORAMIENTO
}

Estudiante: María Teresa Gómez Higuera

Directora: Paula Comellas Angulo

Universidad Santo Tomás de Aquino

Facultad de Derecho

Bogotá D. C.

18 de agosto de 2015 


\section{ÍNDICE}

I. LA CONTRATACIÓN CON ORGANISMOS INTERNACIONALES Y SU

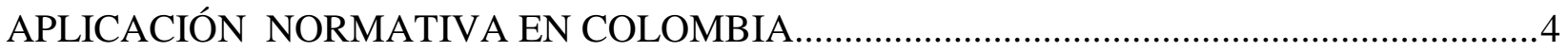

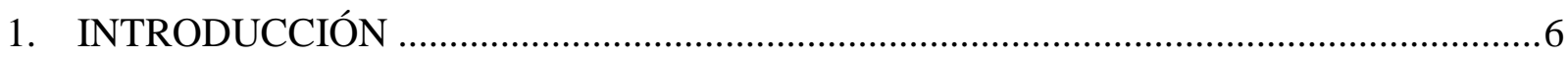

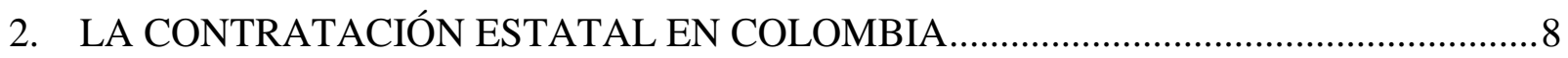

A. Normatividad de la contratación estatal en Colombia ......................................................

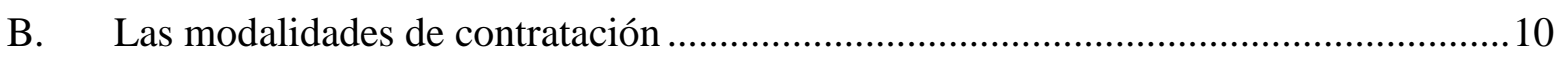

3. PRINCIPALES PROBLEMÁTICAS DE LA CONTRATACIÓN ESTATAL EN

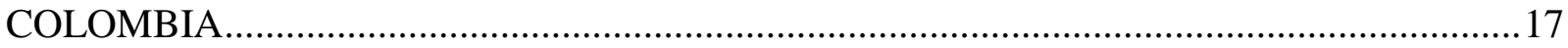

4. LOS ORGANISMOS INTERNACIONALES Y LA COOPERACIÓN

INTERNACIONAL EN EL MARCO DE LA CONTRATACIÓN ESTATAL ….....................19

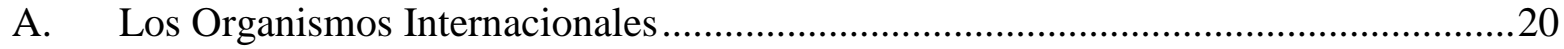

B. La Cooperación Internacional ................................................................................21

C. La cooperación internacional en la contratación estatal ...............................................24

D. La contratación con organismos internacionales ........................................................25

5. LOS CONVENIOS DE COOPERACIÓN Y SU DIFERENCIA CON LOS CONTRATOS

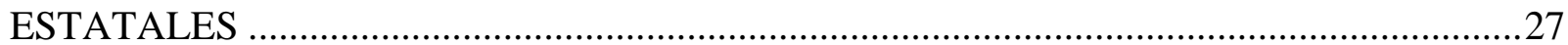

6. REGLAMENTACIÓN LEGAN EN COLOMBIA PARA LA CONTRATACIÓN CON

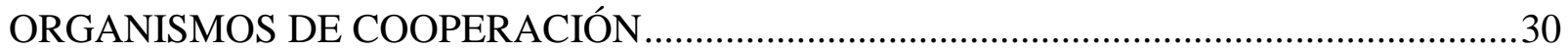

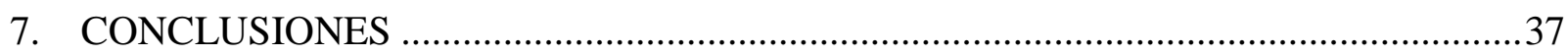

II. LA CONTRATACIÓN CON ORGANISMOS INTERNACIONALES EN EL MINISTERIO DE EDUCACIÓN NACIONAL DURANTE LOS ÚLTIMOS DIEZ AÑOS........39

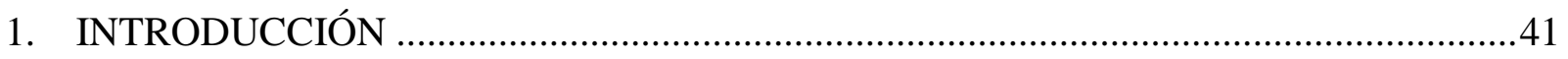

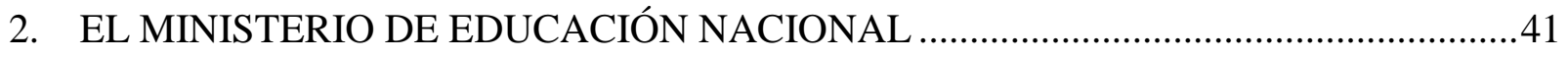

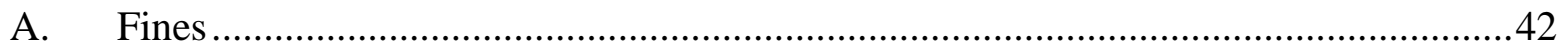

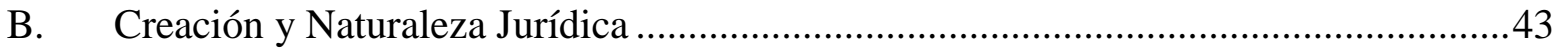

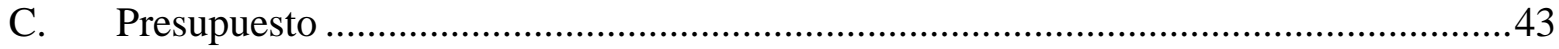

D. Análisis estadístico sobre el presupuesto destinado a Contratación con organismos internacionales.....

3. PRINCIPALES MOTIVOS PARA LA CELEBRACIÓN DE CONVENIOS CON ORGANISMOS INTERNACIONALES EN COLOMBIA ……............................................4
A. Falta de planeación
B. Anualidad del gasto.
C. Sometimiento a las normas de los entes internacionales
D. Vinculación de personal a través de estos convenios .51
E. Demostrar ejecución de recursos 
4. ORGANISMOS INTERNACIONES DE COOPERACIÓN ASISTENCIA O AYUDA

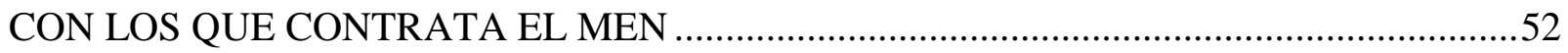

A. La organización para la cooperación y el desarrollo económicos (OECD)

B. La Organización de las Naciones Unidas para la Educación, la Ciencia y la Cultura (UNESCO) .55

C. La Organización de Estados Iberoamericanos (OEI) ...................................................55

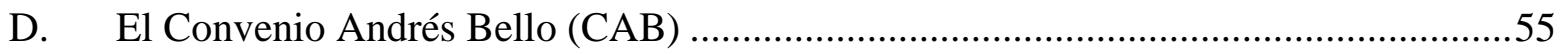

E. El Fondo de Población de las Naciones Unidas (UNFPA) ..........................................56

F. La Organización internacional para las migraciones (OIM) .......................................56

G. El Fondo de las Naciones Unidas para la Infancia -UNICEF ....................................56 5. ANÁLISIS DE CIERTOS CONVENIOS DE COOPERACIÓN INTERNACIONAL SIGNIFICATIVOS SUSCRITOS POR EL MINISTERIO DE EDUCACIÓN NACIONAL ...57

6. ANÁLISIS COMPARADO DE LA CONTRATACIÓN CON ORGANISMOS INTERNACIONALES: EL CASO DE URUGUAY

7. POSIBLES EFECTOS EN LA CELEBRACIÓN DE CONVENIOS DE COOPERACIÓN INTERNACIONAL .63

8. CRÍTICAS A LA CONTRATACIÓN ESTATAL CON ÓRGANOS INTERNACIONALES .67

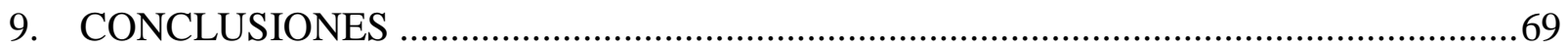

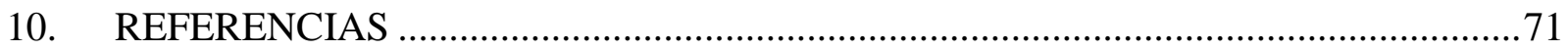




\section{Agradecimientos}

Quiero agradecer a mi familia, a mis padres y hermanos por el apoyo que siempre me brindaron y por la confianza que han depositado en mis logros profesionales; a Andrés por su apoyo y optimismo; a mi amiga Laura por su ayuda constante e incondicional que siempre me brindo para salir avante en este gran logro.

A la Institución que confió en mí, y a mi directora de tesis, Dra. Paula Comellas, por sus grandes aportes, por ser una gran guía; gracias a su constancia, dedicación y conocimientos hoy veo culminado este proyecto.

Asimismo, doy gracias al ser más importante en mi vida, Dios, porque escuchó mis

oraciones y puso en mi camino la oportunidad y los tiempos necesarios para que este trabajo fuera posible. 


\section{LA CONTRATACIÓN CON ORGANISMOS INTERNACIONALES Y SU APLICACIÓN NORMATIVA EN COLOMBIA}

\section{RESUMEN}

En el presente capítulo se expondrá la conceptualización de la contratación estatal con organismos internacionales en Colombia, esto a partir del estudio de elementos teóricos y normativos que componen la contratación pública en el país. El objetivo es realizar un análisis que permita observar si algunos convenios realizados con estos entes están muy alejados de una verdadera cooperación internacional, por cuanto carecen de componente internacional, siendo que su principal objetivo es el de realizar un aporte internacional que sea benéfico en pro del desarrollo del país.

Así las cosas, se evidencia que algunos de los convenios celebrados con organismos internacionales de cooperación constituyen un régimen de excepción que muchas veces utilizan las Entidades para evadir las modalidades de selección previstas en el Estatuto General de Contratación, por tratarse de una contratación que se hace de manera directa.

De otra parte, los convenios celebrados con estos entes, de acuerdo a la normatividad de nuestro país, en su gran mayoría se someten a los reglamentos de tales corporaciones y dejan en situación de desigualdad a la entidad contratante, dado que estos regímenes no contemplan mecanismos que puedan amparar los riesgos que pueden presentarse dentro de su ejecución; por ejemplo, el caso de un eventual incumplimiento, pues no es claro dentro de nuestra legislación cuál sería el órgano competente para conocer de las controversias dentro de esta clase de contrataciones.

Palabras clave: Contratación Estatal, Organismos Internacionales, Componente Internacional, Cooperación internacional, Convenios. 


\begin{abstract}
This chapter will present a conceptualization of state contracts with international bodies in Colombia, that from the study of theoretical and policy elements of the procurement in the country. The aim is to make an analysis to see that the agreements made with these entities are far from true international cooperation, because lack this component, with its main objective is to make an international contribution is beneficial for the development of country.

So, it is evident that some of the agreements concluded with international aid agencies is a special regime often used to evade Entities selection modalities in the General Contracting, by dealing with procurement is done directly.

Furthermore, the agreements concluded with these authorities, in accordance with the regulations of our country, mostly subjected to the regulations of such corporations and leave in an unequal position with the contracting entity, given that these schemes do not provide mechanisms that can protect the risks that may arise in its implementation. For instance, the case of a possible failure, it is not clear in our legislation which the competent body to deal with disputes in this class would be hiring.
\end{abstract}

Key words: Public procurement, International organizations, International component, International cooperation, Agreements. 


\section{INTRODUCCIÓN}

El objetivo de este trabajo de investigación es analizar la contratación entre Organismos de Cooperación Internacional y las entidades estatales en Colombia, la cual muchas veces obedece a improvisaciones por parte de dichas entidades, únicamente, con el fin de cumplir las metas presupuestales propuestas. Esta práctica demuestra una total falta de planeación al momento de su celebración, lo que trae como consecuencia la falta del componente internacional que, por naturaleza, debería reflejarse en los convenios que se suscriben.

Por tal motivo, cabe preguntarse si, dentro del marco de la contratación estatal, la celebración de convenios con organismos internacionales de cooperación en Colombia a través de sus entidades públicas cumple con el aporte internacional; o si, por el contrario, estamos frente a convenios muy onerosos con objetos poco pertinentes que conllevan, entre otras consecuencias, a que las entidades le hagan el quite a los procesos participativos de selección de contratistas.

En este sentido, es preciso abordar, en primera medida, todos los conceptos que componen la contratación estatal, analizando sus modalidades de selección y en especial la contratación directa, como aquella a través de la cual se rigen los convenios de cooperación internacional, objeto de análisis de esta investigación, así como sus problemáticas. Por lo tanto, resulta necesario abarcar el componente netamente conceptual sobre la cooperación internacional que se da entre países a través suscripción de convenios que fomenten el desarrollo de los mismos.

Para alcanzar los objetivos anteriormente señalados se propone una metodología de carácter deductivo realizando un análisis doctrinal, legislativo y jurisprudencial. Lo anterior, tratando de hacer un análisis crítico a la contratación estatal del Ministerio de Educación Nacional con Organismos de Cooperación Internacional.

Finalmente, lo que se espera con esta investigación es considerar si con estos convenios se está realmente frente a la cooperación internacional, y si esta clase de contrataciones trae 
beneficios al Estado Colombiano; o, si se requiere imponer más controles frente a esta serie de contrataciones. 


\section{LA CONTRATACIÓN ESTATAL EN COLOMBIA}

En primer término, se puede afirmar que la Contratación Estatal se encamina a cumplir los fines del Estado como una función pública, la cual es ejercida por las Entidades Estatales a través de sus servidores públicos. De tal forma que, la función pública va ligada a la función administrativa, que es la actividad concreta y práctica desarrollada por el Estado para la obtención inmediata de sus cometidos, pues tiende a concretar en hechos la actividad estatal. (Sayagués Laso, 1953).

A su vez, la Contratación Estatal es vista como función pública o administrativa activa, la cual se puede definir como "aquella por medio de la cual un órgano busca realizar el derecho y cumplir sus fines y cometidos" (Sentencia C-189 de 1998), en la que el servidor público encargado desarrolla sus funciones de conformidad con los fines del Estado a través de una actividad contractual.

Igualmente, la actividad contractual se desarrolla por medio de contratos estatales, cuya definición está contemplada en el Artículo 32 del Estatuto General de Contratación de la Administración Pública (Ley 80 de 1993), que son "todos los actos jurídicos generadores de obligaciones que celebren las entidades a que se refiere el presente estatuto, previstos en el derecho privado o en disposiciones especiales, o derivados del ejercicio de la autonomía de la voluntad".

En tal sentido, la función administrativa, en parte, se desarrolla a través de la celebración de contratos estatales. Estos contratos, en principio, pueden ser idénticos a los de los particulares; pero es dable recordar que la Administración puede celebrar ciertos actos, que si bien son de naturaleza contractual y que se basan en el acuerdo de voluntades, están sometidos a reglas diferentes de aquellas que rigen los contratos ordinarios.(Gómez Lee, 2012)

De lo anterior, se puede decir que la contratación estatal en Colombia está definida como un mecanismo que tiene el Estado, para cumplir, a través de la Administración, con sus fines esenciales y para garantizar la satisfacción de las necesidades públicas que se presenten, esto a través de procesos de selección en los cuales concursan particulares. 


\section{A. Normatividad de la contratación estatal en Colombia}

En Colombia, el origen del reconocimiento de la contratación estatal ha tenido una evolución paralela a la de la jurisdicción contenciosa administrativa, pues esta última prohibía que las resoluciones de las autoridades que tuvieran origen en un contrato fueran acusadas ante dicha jurisdicción. Posteriormente, el Decreto-ley 528 de 1964 trasladó al conocimiento de los tribunales administrativos y del Consejo de Estado ciertos contratos administrativos. (Vidal Perdomo, 1994). Sin embargo, fue con la expedición del Decreto 150 de 1976 que se estableció una regulación unificada aplicable a los contratos que celebre la Nación, la cual contemplaba una amplia normatividad que regulaba los procedimientos como la licitación pública, la licitación privada y la contratación directa. Años más tarde, se expidió el decreto 222 de 1983, el cual incluyó una amplia normatividad que incorpora cláusulas exorbitantes como la terminación, modificación o interpretación unilaterales; procedimientos como la licitación pública y el registro de proponentes; la tipificación de contratos, como el de obra pública, consultoría, suministro, compraventa y servicios.(Castro Cuenca C.; García López, L; Martínez Vargas, J; 2010)

Actualmente, en Colombia existe un marco normativo específico en materia de Contratación Estatal, el cual se denomina "Estatuto General de la Contratación" adoptado por la Ley 80 de 1993. Sin embargo, como se explicará posteriormente, no existen normas unificadoras y/o taxativas que regulen ciertamente la materia; pues existe la posibilidad de incorporar o que algunas discordancias deban ser resueltas a través "de la integración de otras herramientas jurídicas, como la jurisprudencia y la doctrina". (Rosero Melo, 2012)

En concreto, la normatividad vigente aplicable al tema se encuentra, en principio, en la Constitución Política de 1991 y en el régimen de contratación estatal; este último se encuentra regulado en la Ley 80 de 1993, la cual contempla los principios que deben regir la actividad contractual y la Ley 1150 de 2007, la cual modificó en algunos apartes la Ley 80 y varios decretos reglamentarios, en su gran mayoría fallidos que no duraron vigentes por más de un año y que fueron derogados en su integridad, lo que demuestra la falta de seguridad jurídica frente a este tema.(Ramos Acevedo, 2012) 
Por otro lado, existen otros principios que no están regulados en la Ley General de Contratación pero que son de aplicación supletoria. Entre ellos están, por un lado, los principios generales del derecho administrativo, como los de legalidad, publicidad, contradicción, igualdad, enriquecimiento sin causa, abuso del derecho, entre otros; además, están los principios que rigen la función administrativa, como el de economía, celeridad, eficacia, planeación, moralidad e imparcialidad, los cuales son preexistentes del Decreto 01 de 1984; de tal forma que, todos estos principios constituyen un "bloque de legalidad" (Santofimio Gamboa, 2004, pág. 36) de las actuaciones administrativas, tal y como lo afirma el autor en mención.

De lo anterior, se puede apreciar que la normatividad en contratación estatal está enmarcada en una serie de normas, leyes y decretos que en su interpretación presentan algunos vacíos que conllevan a la inseguridad jurídica y por ende, su aplicación puede redundar en casos de ilegalidad de los actos que se profieran con ocasión de la actividad contractual.

\section{B. Las modalidades de contratación}

Definido el marco teórico de la Contratación Estatal desde una perspectiva conceptual, se dará una mirada a las modalidades de selección de contratistas establecidas en el actual Estatuto de Contratación.

Históricamente, en el régimen liberal que surgió después de la Revolución Francesa se desconfiaba de la autoridad pública, lo que se ve reflejado en la libertad de competencias públicas; por ello durante el periodo clásico del Estado liberal, se estaba en contra del principio de que la Administración pueda elegir libremente a su co-contratante y establecer sus propias reglas, se consolida el mecanismo de contratación mediante licitación pública como instrumento rígido y reglado, y por supuesto restrictivo a los poderes discrecionales de los agentes del Estado. (Dromi, 1977).

Más adelante, con la intervención de Estado Liberal Clásico, a raíz de la mayor intervención del Estado dentro de la economía, se fue matizando este principio por los desestímulos del 
procedimiento licitatorio, lo que generó nuevos procedimientos de selección como la licitación privada y la contratación directa.(Dromi, 1977)

Como se mencionó anteriormente, en Colombia los Contratos Estatales se rigen por el Estatuto General de Contratación Pública, Ley 80 de 1993, reformado por la ley 1150 de 2007 y varios decretos reglamentarios), y para su celebración deben observar los principios de la Función Administrativa y la Contratación Estatal; igualmente, deben aplicar, previo a su celebración, los denominados procesos de selección, esto con el fin de lograr la más amplia participación de los ciudadanos, pues se busca las mejores ofertas para garantizar la eficiente prestación de los servicios públicos y el beneficio de los intereses de los administrados que colaboran en la consecución de los fines del Estado (Hincapie, 2008).

Así las cosas, en Colombia, por regla general, la modalidad de selección aplicable para la escogencia de contratistas de acuerdo al régimen de contratación estatal en Colombia, es la licitación pública que se fundamenta principalmente en tres principios: la libertad de concurrencia, la publicidad, y la igualdad, los cuales deben ser respetados por la Administración pública, pues cualquier acto de la entidad pública que vulnere estos postulados comporta la nulidad del proceso licitatorio por vicio de forma y violación del régimen jurídico.(Marienhoff, 1990).

Por su lado, el Estatuto de contratación estatal, adoptado por la Ley 80 de 1993, señalaba que la regla general para la selección de contratistas era la licitación o el concurso público y excepción, la contratación directa. Sin embargo, la modalidad de la licitación pública se convirtió en la excepción, pues los servidores públicos encargados de la contratación en distintas entidades siempre buscaron aplicar permanentemente la contratación directa (Morales Restrepo, 2012).

Posteriormente, debido a los vacíos que presentaba la Ley 80 de 1993, después de varios intentos de reformas se expidió la Ley 1150 de 2007, que modificó el Estatuto de Contratación de la Administración Pública e introdujo medidas para la eficiencia y la transparencia de la Contratación. La Ley 1150 estableció las siguientes modalidades de participación: licitación 
pública, selección abreviada, concurso de méritos y contratación directa. Sin embargo, a pesar de la reforma, la Contratación Pública seguía presentando vacíos, los que pasaron a ser regulados por Ley 1474 de 2011. Esta Ley adoptó el Estatuto Anticorrupción y estableció el procedimiento de mínima cuantía para la contracción que no exceda más del 10\% de la cuantía de cada entidad.

En síntesis, la licitación pública constituye la regla general de contratación. Por otro lado, la selección abreviada es una modalidad de selección que se encuentra regulada en la Ley 1150 de 2007 y tiene como finalidad la eficiencia y la transparencia en la contratación, pues tiene previstos taxativamente los casos en los que debe contratar. De igual forma, a través de esta modalidad se pretende "la realización de procedimientos ágiles y expeditos, para aquellos eventos en que las características del bien o las circunstancias de la contratación así lo permitan" (Reyes Yunis, 2007), esto es, que la contratación cuente con un procedimiento ágil y eficiente para que las entidades públicas adquieran bienes de características uniformes en los casos señalados por la Ley.

En tercer lugar está el Concurso de Méritos, el cual corresponde a la modalidad prevista para la selección de consultores o proyectos, "en la que se podrán utilizar sistemas de concurso abierto o de precalificación"1.

\section{a. Los Procesos de Selección participativos y sus etapas}

Según RODRIGUEZ, el fin del Estado Colombiano es servir a la comunidad, promover la prosperidad general y garantizar la efectividad de los principios, derechos y deberes consagrados en la Constitución Política; por ende, a través de los procesos de selección se debe " facilitar la participación de todos en las decisiones que los afectan y en la vida económica, política, administrativa y cultural de la Nación; defender la independencia nacional, asegurar la convivencia pacífica y la vigencia de un orden justo, a través de la función administrativa pues está al servicio de los intereses generales y se desarrolla en aplicación en los principios de igualdad, moralidad, eficacia, economía, celeridad, imparcialidad y publicidad" (Rodríguez, 1994).

\footnotetext{
${ }^{1}$ Artículo. 2.3. de la Ley 1150 de 2007.
} 
En aplicación de los principios que rigen la contratación estatal, se han establecido los procesos de selección participativos dentro de los cuales se permite que concurran todos aquellos ciudadanos capaces e idóneos, interesados en desarrollar el objeto que se pretende contratar; esto a través de la participación en los denominados procesos de: licitación pública, selección abreviada, concurso de méritos y mínima cuantía, los cuales comprenden un serie de etapas en su desarrollo en aras del principio de transparencia del proceso contractual.

En primer término, el Estatuto de contratación estatal establece que las entidades interesadas en contratar deberán realizar estudios que permitan establecer la viabilidad y condiciones técnicas, económicas y de conveniencia de la contratación a celebrar, los cuales deberán contener un análisis del mercado que le permita a la entidad determinar el presupuesto de la contratación, así como los precios de referencia. Estos documentos previos son los que soportan el Pliego de Condiciones considerado como el documento en el cual se establecen las reglas del proceso de contratación (Fandiño Gallo, 2009).

Ahora bien, el pliego de condiciones, según la Corte Constitucional, es un acto jurídico prenegocial con carácter vinculante y obligatorio para los partícipes del proceso de licitación. En este proceso, el principio fundamental informador de la etapa de selección del contratista es el de garantizar la igualdad de los oferentes. Es decir, la administración no puede establecer criterios irrazonables que no consulten el interés general presente tanto en el proceso de selección como en la ejecución del contrato estatal, so pena de ineficacia de dichas cláusulas predispuestas ante casos de violación mayúscula del ordenamiento jurídico v. gr. contravención de norma de orden público. (Sentencia No. 16209 Consejo de Estado, (2007).

En ese orden de ideas, el momento de la elaboración de los estudios previos y pliego de condiciones podemos definirlo como la etapa precontractual del proceso de contratación; que, según HERRERA BARBOSA, debe estar precedida de la planeación de la contratación, donde se determina: la conveniencia, la oportunidad, la determinación del presupuesto, el impacto social, económico, ambiental, el tiempo que durará el desarrollo del futuro contrato, entre otros. Estos elementos permiten planear de manera efectiva la contratación adelantada por cualquier 
ente estatal, la cual, como se ha venido mencionado, debe estar orientada a satisfacer el interés público y las necesidades del Estado. (Herrera Barbosa, 1996)

Esta etapa precontractual comprende la publicación del pliego de condiciones del proceso hasta la adjudicación del respectivo contrato. Respecto a esto, los términos y condiciones de la contratación están plasmados en el pliego de condiciones, el cual, a su vez, cuenta con una serie de pasos o etapas del desarrollo del proceso, a saber: las observaciones de los posibles interesados en participar, la presentación de las propuestas y la evaluación de las mismas. En este proceso la escogencia del contratista se hace bajo los principios de la contratación y en especial bajo el de selección objetiva. (Herrera B., Riveros H., \& León L. 1996).

Posteriormente, una vez adjudicado el contrato a la mejor oferta, comienza la etapa contractual. En esta etapa se desarrolla del objeto contractual y se da la contraprestación correspondiente por parte del contratista y contratante, respectivamente; siempre de conformidad con la forma, plazos y condiciones pactadas. No obstante, previo a la ejecución del contrato, la entidad lo debe haber perfeccionado y legalizado; es decir, lo debe haber suscrito, tener el correspondiente registro presupuestal, la aprobación de las garantías que amparan el cumplimiento del mismo y su posterior publicación (Gámes Vizcaino, 2002).

Por otro lado, una vez cumplido el plazo de ejecución del contrato, se procederá a la liquidación del mismo, actuación que se encuentra dentro de la etapa postcontractual, y que comprende "todas las actuaciones posteriores al vencimiento del término establecido en el contrato, o en el acto que lo da por terminado de manera anticipada" (Vega de Herrera \& Ordoñez Maldonado, 1999).

En resumen, podemos ver que la formación del contrato estatal se basa en tres etapas, de las cuales depende el régimen jurídico aplicable o modalidad de selección: "la precontractual: que corresponde al proceso que inicia con la determinación de las necesidades públicas y culmina con la escogencia del contratista; la contractual, que va desde la firma del contrato hasta la finalización del plazo contractual y la post contractual que es la culminación y liquidación del contrato” (Herrera Robles, 2012). 
Se puede afirmar, entonces, que los procesos de selección participativos son aquellos en los cuales concurre más de un interesado a través de una convocatoria pública abierta y participativa, que se desarrollan conforme a ciertas etapas definidas en el Estatuto de la Contratación, tales como la precontractual, contractual y pos contractual.

Ahora, realizado el esbozo de los procesos de selección participativos y sus etapas, nos adentraremos en aquellos procesos de selección que se hacen de manera directa, sin que sea necesario contar con más de un interesado para su celebración, y específicamente es la Contratación Directa, en esta el contratante se reserva la potestad de escoger libremente a su contratista.

\section{b. La Contratación Directa}

La contratación directa es el procedimiento mediante el cual las entidades estatales celebran los contratos autorizados por el numeral $4^{\circ}$ del artículo $2^{\circ}$ de la Ley 1150 de 2007 sin que sea necesaria la obtención previa de varias ofertas. Por esta razón, este procedimiento ha sido denominado de "libre selección del contratista". Es decir, que es aquella modalidad de contratación que, por no estar precedida de un proceso de selección riguroso, es más ágil que las otras modalidades de selección, siendo este un aspecto que interesa a todas las entidades estatales, pues el tiempo que conlleva un proceso de selección resulta siendo el mayor enemigo de la contratación estatal cuando no se cuenta con una buena planeación (Súarez Beltrán, 2007).

En términos generales, la contratación directa es un mecanismo excepcional de selección, que "encuentra su justificación en el orden público e interés general que debe satisfacer la administración" (Romero Pérez, 2002). Modalidad "que gracias a su naturaleza" ha sido generadora de una serie de inconvenientes en la transparencia de la contratación estatal del país, pues como se explicará posteriormente sus características hacen que la entidad estatal sea quien escoja libremente al contratista justificando la necesidad de contratar directamente y obviar los procesos de selección anteriormente descritos. 
En consecuencia, es posible afirmar que la contratación directa se caracteriza por tener un procedimiento ágil y corto, no abierto y participativo, ausente de la rigurosidad de la etapas de los procesos participativos, lo que genera que en muchas ocasiones se desconozcan los principios rectores de la contratación estatal, ya sea por el interés particular de quien contrata o por la necesidad contractual (Mutis Vargas \& Quintero Munera, 2000).

Ahora bien, todos los procesos contractuales, sean participativos o directos, deben respetar los principios de la contratación y en especial, para la contratación directa, el de selección objetiva, el cual se constituye en "una regla de conducta de la actividad contractual y un principio que orienta los procesos contractuales de selección, tanto de licitación pública como de contratación directa, y un fin, pues apunta a un resultado, cual es, la escogencia de la oferta más ventajosa para los intereses colectivos perseguidos con la contratación" (Concepto Procuraduría Delegada ante el Consejo de Estado No. 298 /2012).

En relación con lo anterior, el Consejo de Estado ha afirmado que cuando se habla de selección objetiva se refiere " $a$ un deber que es necesario llevar en el procedimiento o trámite que se utilice para elegir al contratista, de manera que están sometidos a él no sólo la licitación pública y el concurso de méritos, sino también la contratación directa” (Sentencia 12932, 2004).

De tal forma que, no por ser la contratación directa aquella modalidad que no requiere de un proceso de selección previo abierto y con la participación de ciudadanos interesados en ejecutar el objeto requerido por la Entidad, es admisible que los encargados de su aplicación, unas veces por ignorancia y en otras en presencia de un dolo evidente, hagan uso equivocado de sus causales y terminen concluyendo que la contratación directa constituye una derogación de los principios que rigen la contratación pública, así lo ha manifestado el honorable Corte Constitucional mediante sentencia C-508-02 (M.P. Alfredo Beltrán Sierra).

Por consiguiente, la contratación directa no puede implicar la exclusión o inaplicación de los principios rectores de la actividad contractual, pues estos garantizan la objetividad en la selección del sujeto que se ajuste a la necesidad del Estado, tal como lo señaló la Corte Constitucional, "la potestad de contratación directa debe ejercerse con estricta sujeción al 
reglamento de contratación directa, actualmente consignado en el Decreto 855 de 1994, cuyas disposiciones, conforme al parágrafo del artículo 24 de la Ley 80, precisamente, buscan garantizar y desarrollar los principios de economía, transparencia y, en especial, el deber de selección objetiva establecidos en el Estatuto Contractual" (Sentencia C-040/0, 2000)

Lastimosamente, esta forma de contratación directa ha permitido que se asocie de forma equivocada, por supuesto, con el procedimiento menos transparente de escogencia de contratistas del Estado, pues es en ésta, donde pueden existir favorecimientos para ciertos contratistas y pueden llegar a presentarse focos de corrupción.

Ahora bien, el Estatuto General de Contratación trae algunas excepciones que no se encuentran dentro de las causales de contratación directa, pero que de alguna forma se hacen directamente, es decir sin un proceso abierto y participativo de selección; por ejemplo, la contratación con organismos internacionales de cooperación, así, a través de esta modalidad se recusa el procedimiento contractual establecido para generar actividades negociales con organismos internacionales, pues su objetivo principal es aportar componentes internacionales a Colombia, pero se ha utilizado para evadir las modalidades de selección, resultando ser ineficiente la contratación estatal.

\section{PRINCIPALES PROBLEMÁtiCAS DE LA CONTRATACIÓN ESTATAL EN COLOMBIA}

Teniendo en cuenta lo anterior, podría afirmarse que una de las mayores problemáticas de la Contratación Estatal en Colombia es el desequilibrio normativo y el conflicto de intereses al momento de contratar. Pues el marco jurídico de la contratación estatal en Colombia ha estado signado históricamente por su inestabilidad normativa, generadora indiscutible de inseguridad jurídica, no solo frente a los operadores de aquella, sino también en lo fundamental respecto de la generalidad de los asociados dispuestos, cotidianamente, a relacionarse de manera contractual con el Estado en un ambiente de igualdad y competencia leal (Santofimio Gamboa, 2009). 
Así las cosas, se puede evidenciar que el régimen de Contratación en Colombia, no es más que una colcha de retazos, pues con ocasión de la reforma de la ley 80 de 1993 y con la expedición de la ley 1150 de 2007 se han suscitado una serie de decretos reglamentarios que no han tenido más de un año de vigencia. Esto conduce a la idea de que cada uno de estos decretos forman parte de una serie de improvisaciones, que muchas veces cae en posibles vicios de legalidad e inconstitucionalidad. (Pino Ricci, 2005). Error mayúsculo que se mantuvo con la reforma de la Ley 1150 de 2007, al continuar con la improvisación, en la medida que no se evaluaron convenientemente en su momento las orientaciones de los organismos internacionales en materia contractual, entidades que parten de un uniformismo tecnocrático de difícil recibo frente a las características de la problemática administrativa Colombiana. (Santofimio Gamboa, 2009).

Otra de las problemáticas de la contratación es la falta de planeación de las entidades estatales en sus contrataciones, que a su vez viene de la mano del plazo límite dado por el llamado principio de anualidad para la ejecución de los recursos púbicos, el cual comprende que los recursos deben ejecutarse durante la vigencia fiscal en que les fueron asignados, tiempo que muchas veces resulta corto para la ejecución eficiente de los mismos. Aquellos gastos autorizados en un presupuesto han de llevarse a cabo en el mismo año para el que se ha aprobado tal presupuesto, so pena de quedar anulada tal autorización (Naranjo Flórez \& Cely Cubides, 2008).

El principio de anualidad del presupuesto ha sido consagrado en el artículo 346 de la Constitución Política respecto de la aprobación, y en el artículo $8 .^{\circ}$ inciso 1 de la Ley 819 de 2003 en lo referente a la ejecución, en los siguientes términos: "La preparación y elaboración del presupuesto general de la Nación y el de las entidades territoriales deberá sujetarse a los correspondientes marcos fiscales de mediano plazo de manera que las apropiaciones presupuestales aprobadas por el Congreso de la República, las asambleas y los concejos puedan ejecutarse en su totalidad durante la vigencia fiscal correspondiente" (Ramírez, 2009).

Ahora bien, el principio de anualidad puede ser superado por las denominadas vigencias futuras, que no son más que autorizaciones que se tramitan ante el Ministerio de Hacienda para comprometer recursos de vigencias de años posteriores y así poder extender los términos de 
ejecución de los contratos en aquellos casos que se requieran. Además, la falta de planeación no permite que estos trámites se hagan en el tiempo y oportunidad debida, lo que conlleva a celebrar contrataciones apresuradas, con tiempo de ejecución muy corto e irracional y algunas veces poco pertinentes y beneficiosos para las necesidades del Estado (Ministerio de Hacienda , 2012).

Otro factor que puede considerarse como problemática es la corrupción que existe de algunos servidores públicos, pues no invierten de manera correcta y justa los recursos y de alguna forma se hace más susceptible la desviación de los mismos, o las contrataciones que resultan siendo extremadamente onerosas para el Estado, poco pertinentes y muchas veces innecesarias, que no traen beneficios ni llegan a ser efectivas para el cumplimiento de los fines del Estado.

Por último, una de las más duras criticas y problemáticas en la contratación estatal del país es la de castigar aquellas entidades que no ejecutan la totalidad de los recursos asignados en cada vigencia presupuestal, es decir del 1 de enero a 31 de diciembre de cada año, pues esta regla conlleva a que en el afán de cumplir con la metas propuestas y demostrar gestión, las entidades terminan comprometiendo recursos con contrataciones no planeadas y con objetos poco beneficios para el Estado, lo que puede conllevar sanciones a los servidores públicos por sus malas prácticas en la equivocada inversión de los recursos públicos.

\section{LOS ORGANISMOS INTERNACIONALES Y LA COOPERACIÓN INTERNACIONAL EN EL MARCO DE LA CONTRATACIÓN ESTATAL}

Previo al desarrollo del concepto de Organismos Internacionales es importante señalar lo que se entiende por cooperación internacional. La cooperación internacional "en su concepto tradicional, se conoce como la ayuda oficial dirigida a los países en vías de desarrollo por parte de los países avanzados o por organismos multilaterales de cooperación "norte - sur". A partir de 1978 se incorporó en el concepto la cooperación técnica entre países en desarrollo - CTPD, o cooperación sur - sur, que es efectuada por países de similar nivel de desarrollo (Concepto Secretaria General - Arcadia de Bogotá 72 de 2008). Por su parte, los organismos internacionales o de cooperación son "organismos creados por los Estados y para los Estados" (Figueroa Pla, 1991). 


\section{A. Los Organismos Internacionales}

Los organismos u organizaciones internacionales nacen del desarrollo del Derecho internacional y son asociaciones voluntarias de Estados establecidas por acuerdo internacional, dotadas de órganos permanentes, propios e independientes encargados de gestionar unos intereses colectivos y capaces de expresar una voluntad jurídicamente distinta de la sus miembros.(Diez, 1997).

En este sentido, los organismos son de dos clases: las organizaciones intergubernamentales, es decir, las compuestas por varios Estados y que nacen muchas veces de tratados o acuerdos internacionales, y las organizaciones no gubernamentales que nacen regularmente por un acto del derecho interno y que pueden ser fundaciones, instituciones o asociaciones sin ánimo de lucro, se caracterizan por ser entidades privadas que abarcan actividades humanas tales como las artísticas, culturales sociales, etcétera. (Figueroa Pla, 1991). Las primeras organizaciones son personas jurídicas de derecho internacional distintas de la de sus Estados miembros. Por tanto, las organizaciones internacionales tienen capacidad de ser titulares de derechos y obligaciones tanto en las relaciones con otros sujetos de Derecho Internacional, como respecto del ejercicio de sus funciones en el territorio de algún Estado.(Diez, 1997).

De tal manera que, los organismos internacionales se caracterizan como "instituciones creadas por sus Estados participantes, con el propósito de imponer, elaborar y modificar leyes internacionales, dependiendo de las legislaturas de los Estados" (Bueno de Mesquita, 2006). Es decir, que estos organismos forman parte del sistema internacional, teniendo la facultad de crear y modificar las normas y reglas internacionales. (Monroy, 2011)

Sin embargo, en la materia objeto de estudio en esta investigación, los organismos internacionales que resultan relevantes son aquellos que, más que imponer elaborar y modificar preceptos normativos de carácter internacional, contengan un enfoque funcional; es decir, que su interés se encuentre concentrado en asuntos de ciencia, infancia, trabajo, cultura, etcétera, que “ 
podrían no solo avanzar hacia un desarrollo económico y social sino además una construcción funcional de Estados y cooperación" (Maldonado Bodart, 2013).

Ahora bien, los Organismos de Cooperación Internacional, según el Estatuto de Contratación Estatal, pueden clasificarse de la siguiente manera: fondos multilaterales de crédito, personas extranjeras de derecho público y organismos de cooperación, asistencia o ayuda internacional.

Por su parte, los fondos multilaterales de crédito son instituciones financieras conformadas por una serie de países interesados en promover la cooperación económica internacional y regional con el fin de promover y mejorar las relaciones comerciales y brindar ayuda financiera encaminada a programas sociales (Álvarez, Giancolome, \& Sandoval, 1998). Por otro lado, dentro de las personas extranjeras de derecho público encontramos a los Ministerios y entes territoriales de países extranjeros. Por último, los organismos de cooperación, asistencia, o ayuda internacional prestan ayuda oficial dirigida a los países en vías de desarrollo por parte de los países avanzados o por organismos multilaterales de cooperación "norte - sur" (Taborda, 2012).

De esta forma, los organismos internacionales son de carácter global y universal, cuya función va dirigida al desarrollo de los países que lo conforman. Es por esta razón que, en materia de contratación estatal y para efectos de la presente investigación, cuando se hable de organismos internacionales se hará referencia a los organismos de carácter especializado, es decir, aquellos que cuentan con un asunto y/o función específica en pro del desarrollo y la cooperación internacional de los países miembros.

\section{B. La Cooperación Internacional}

Entre tanto, una vez definida de manera general la cooperación internacional en el inicio de este aparte; resulta razonable indicar que este concepto, se encuentra en los principios universales de solidaridad entre los pueblos, respeto y protección de los derechos humanos y en la búsqueda incesante de mejores condiciones y mayores recursos que brinden al hombre una 
situación de bienestar conforme a su dignidad humana, fin último de la existencia de los Estados.(Presidencia de la Republica- Acción Social, 2007), que al encontrarse íntimamente ligado a las relaciones internacionales, encuentra su fundamento jurídico en el derecho internacional, que es aquella disciplina que estudia las relaciones entre los Estados y entre estos y los organismos internacionales.

En otros términos, la cooperación se refiere a una ayuda, un auxilio, la solidaridad entre los sujetos desde su ámbito competencial que ejecutan actividades que interesan mutuamente a las partes para alcanzar un fin común de forma más eficaz. Es decir, cada una de las partes ejerce sus propias competencias, que son diferentes pero que es necesario relacionar para efectos de realizar la función administrativa de una manera más eficiente (Chávez, 2008).

En materia de derecho internacional, esta cooperación comprende las diversas acciones que realizan actores públicos o privados con el propósito de promover el progreso económico en países de menor renta relativa comúnmente denominados "países del sur" o países en vías de desarrollo (Pierri, 2009).

En términos generales, lo que se busca con la cooperación internacional, a través de los organismos llamados de cooperación, es la ayuda internacional que representa una inversión esencial para el desarrollo humano y su beneficio se puede medir en el potencial humano que se deriva de la prevención de enfermedades y muertes evitables, la educación, la superación de las desigualdades de género y la creación de condiciones para conseguir un crecimiento económico sostenido y con una mejor distribución del ingreso.(Maldonado Bodart, 2013)

Por consiguiente, la cooperación internacional se puede entender como la ayuda que se entrega para apoyar el desarrollo económico y social de los países en desarrollo mediante la transferencia de tecnologías, conocimientos, habilidades o experiencia por parte de los países $\mathrm{u}$ organizaciones internacionales, se le conoce también como Ayuda Oficial al Desarrollo (AOD). http://www.apccolombia.gov.co/recursos_user//Documentos/Manual-Formulacion-proyectos.pdf) 
Así las cosas, es preciso afirmar que el principal objetivo en celebración del contrato o convenio con un organismo de cooperación internacional debe contener un aporte internacional en pro del desarrollo del país; el cual se constituye en el objeto principal y define la naturaleza del acto jurídico a celebrar, pues es esta la motivación que siempre debe existir para celebrar este tipo de contratos. 


\section{La cooperación internacional en la contratación estatal}

Una vez entendida la cooperación internacional como "la forma en que los países desarrollados brindan ayuda a los países subdesarrollados, a través de la transferencia de tecnologías, conocimientos, habilidades, o experiencias por parte de países u organizaciones multilaterales con el fin de cumplir metas de desarrollo" (Zambrano \& Salazar, 2012); es dable mencionar que la contratación estatal es el medio por el cual se dan las distintas modalidades de contratación, que impactan a los procesos de cooperación internacional, pues la admisión de la "ayuda internacional" se realiza por medio de un convenio de cooperación, el cual va dirigido a contribuir al desarrollo de los países con menor nivel de desarrollo en áreas específicas; por ejemplo, Colombia.

La Cooperación internacional ha sido uno de los mayores logros en el marco del Derecho Internacional, pues a través de esta se han desarrollado proyectos exitosos para aquellos países en vía de desarrollo con la ayuda de países desarrollados. Todo esto se ha logrado a través de las distintas categorías de cooperación que existen y de las cuales Colombia ha sido un gran beneficiado. Dentro de estas categorías de Cooperación Internacional podemos enunciar las siguientes:

a) Cooperación Financiera: La cual puede ser: i) Reembolsable: a través de préstamos a los países en vía de desarrollo con facilidades como intereses bajos, periodos de gracia y amplios plazos de pago. ii). No reembolsable: se asignan recursos financieros sin exigir el reembolso de los mismos, solo se espera el éxito de proyecto que se financia. Esta cooperación la realizan generalmente los Bancos multilaterales como el Banco Mundial, el Banco Interamericano de Desarrollo entre otros.

b) Cooperación Técnica: Abarca la transferencia de conocimientos, habilidades y experiencias por parte de países u organizaciones con un nivel de desarrollo más avanzado con el fin de contribuir con el fortalecimiento de las capacidades, el avance tecnológico, educación, entre otros. 
c) Ayuda Humanitaria y de Emergencia: Se presta cuando se presentan catástrofes naturales o conflictos armados, y tienen el objetivo de aliviar el sufrimiento de la población afectada, así como garantizar su subsistencia. Para asignar este tipo de ayudas es necesario que el gobierno beneficiario no pueda asumir el fenómeno con sus propios recursos y que la situación sea considerada como anormal.

d) Ayuda Alimentaria: La ayuda alimentaria es la asignación de productos alimentarios para poblaciones que no pueden asumir su abastecimiento ni su seguridad alimentaria, con el fin de apoyar sus procesos de desarrollo. Los recursos alimentarios pueden ser donados o vendidos con porcentajes condonables o créditos blandos. Esta ayuda puede ser bilateral, multilateral o no gubernamental. Los productos alimentarios se pueden entregar en el marco de programas de ayuda alimentaria de los países donantes, o se pueden realizar ayudas por situaciones de emergencia derivadas de un desastre.

e) Cooperación Cultural: Destina recursos a la realización de actividades en áreas culturales para el fortalecimiento de la identidad cultural, la protección de la diversidad cultural y las lenguas minoritarias, el fortalecimiento de los proyectos artísticos, la promoción del diálogo intercultural, la educación y la cohesión social, entre otros. Las actividades de cooperación cultural se realizan entre museos, casas de la cultura, grupos culturales, Ministerios de Cultura, etc. (Manual de acceso a la cooperación internacional APC, 2011 Bessudo S, Estrada, J 1 Olarte Suescun, J Tenorio C.)

\section{La contratación con organismos internacionales}

Esta forma de contratación estatal se desenvuelve dentro del marco de la cooperación internacional, y se materializa a través de convenios de cooperación, que se celebran con personas naturales o jurídicas de derecho público o privado, quienes se comprometen a lograr ciertos objetivos, para lo cual unen esfuerzos a través de aportes, ya sea en dinero o en especie a 
fin de llevar a cabo las actividades necesarias para el logro de sus fines (Matallana Camacho, 2004).

En Colombia esta modalidad de contratación se refiere a la suscripción de los llamados convenios de cooperación con organismos internacionales, regulados en la última reforma al Estatuto de Contratación Estatal vigente a través del artículo 20 de la ley 1150 de 2007 "Por medio de la cual se introducen medidas para la eficiencia y la transparencia en la Ley 80 de 1993 y se dictan otras disposiciones generales sobre la contratación con Recursos Públicos", modificado por el artículo 157 del Decreto 1510 de 2013, derogado por el artículo 2.2.1.2.4.4.4 del Decreto 1082 de 2015, el cual analizaremos más adelante.

Por su parte, una de las características que hacen que la contratación con organismos internacionales sea una modalidad especial de contratación, es que el objeto principal de la celebración de los convenios de cooperación es el aporte internacional, el cual demuestre las buenas prácticas internacionales a través de proyectos exitosos que expongan y permitan el desarrollo del país en vía de desarrollo. De tal forma que, por medio de la contratación con organismos internacionales, se busca el cumplimiento de los fines del Estado, pues resulta beneficioso para un país, el aporte internacional que propenda por su rápido desarrollo económico y social (Torres Vega, 2011).

De conformidad con lo anterior, resulta viable determinar en esta investigación quiénes son los sujetos del acto jurídico que permite la contratación entre un ente estatal y un organismo internacional, pues como se mencionó en punto anterior, respecto de esta modalidad especial, existen muchos vacíos normativos que hacen que en la práctica la contratación no cumpla con su naturaleza.

En primer lugar, es importante mencionar que el sujeto activo es el Estado Colombiano, quien actúa a través de una Entidad Estatal y que en Colombia son aquellas relacionadas en el artículo $2^{\circ 2}$ de la Ley 80 de 1993. Este sujeto cuenta con una capacidad presupuestal para

\footnotetext{
${ }^{2}$ Artículo $2^{\circ}$ ley 80 de 1993. ) La Nación, las regiones, los departamentos, las provincias, el Distrito Capital y los distritos especiales, las áreas metropolitanas, las asociaciones de municipios, los territorios indígenas y los municipios; los establecimientos públicos, las empresas industriales y comerciales del Estado, las sociedades de economía mixta en las que el Estado tenga participación superior al cincuenta por ciento (50\%), así
} 
celebrar contratos ${ }^{3}$ a nombre de la persona jurídica de la cual es parte; a su vez, es la encargada de ordenar el gasto de las apropiaciones incorporadas al presupuesto de su entidad a través de contratos y convenios para el cumplimiento de los fines y metas propuestos.

Por otro lado, como sujeto pasivo se encuentra el Organismo Internacional quien actúa como sistema para lograr metas y objetivos de carácter internacional (Rocuts \& Barreiro). Algunos de estos organismos actúan como fuentes multilaterales, es decir, aquellos "organismos internacionales en los cuales participan varios países con intereses determinados de carácter político, regional o sectorial. Estos organismos multilaterales otorgan o ejecutan cooperación con sus propios recursos o con fondos entregados por los países miembros para programas concretos" (Corredor, 2009).

Así las cosas, las partes suscribientes en el contexto de la contratación estatal, en el marco de la cooperación internacional son las Entidades Estatales y los Organismos internacionales especializados que actúen como fuente multilateral a través de la cooperación internacional, que plasman su acuerdo de voluntades para el cumplimiento de los fines propuestos a través de los llamados convenios de cooperación internacional.

\section{LOS CONVENIOS DE COOPERACIÓN Y SU DIFERENCIA CON LOS CONTRATOS ESTATALES}

Una vez establecida la modalidad contractual sobre la que versa la contratación estatal con organismos internacionales en Colombia, conviene decir al respecto como ya se mencionó previamente que esta forma de contratación se refiere a la suscripción de convenios de cooperación, los cuales se diferencian conceptualmente con los contratos estatales.

En primer lugar, en términos generales se puede afirmar que el contrato es aquel acuerdo de voluntades productor de efectos jurídicos, en el cual los sujetos intervienen abrigando intereses disímiles y contrapuestos con prestaciones reciprocas; mientras que el convenio es un

como las entidades descentralizadas indirectas y las demás personas jurídicas en las que exista dicha participación pública mayoritaria, cualquiera sea la denominación que ellas adopten, en todos los órdenes y niveles.

3 Decreto 111 1996, Articulo 110 
negocio jurídico que participando también del carácter formal de la condición contractual, es decir, siendo un acuerdo de voluntades con efectos jurídicos, vincula a las personas con el ánimo de realización de efectos comunes a ambas partes con la única contraprestación de cumplir el fin propuesto.(Chávez, 2008).

Así las cosas, teniendo en cuenta que el contrato es un acuerdo de voluntades generador de obligaciones que se utiliza en las diferentes áreas de ordenamiento como instrumento para facilitar el intercambio de prestaciones propio de las relaciones patrimoniales de la sociedad moderna y de la naturaleza social del hombre(Alessandri, 2000), podría afirmarse que no todo contrato constituye un convenio, por cuanto éste último hace referencia a la confluencia de intereses y el contrato contradicción de causas y de fines (Cassagne, 1981).

Por regla general, los contratos que celebran las entidades estatales se denominan contratos administrativos; por ende, se les atribuyó la competencia a la jurisdicción contencioso administrativa, la cual adoptó ciertas cláusulas excepcionales de interpretación, modificación o terminación unilateral y caducidad frente al contratista y en favor de la administración (Parada, 2008).

Ahora, también existen tipos de actividad de la Administración en las cuales no existe la finalidad de obtener algún tipo de lucro, sino colaborar con la entidades estatales para velar por el desarrollo desde el punto de vista social, no económico. Esto es lo que la doctrina ha llamado convenios de la Administración, definidos como "el negocio jurídico bilateral de la administración en virtud de la cual esta se vincula con otra persona jurídica pública o con una persona jurídica o natural privada para alcanzar fines de interés mutuo en el marco de la ejecución de funciones administrativas, fines, que como es obvio, siempre deberán coincidir con el interés general (Santos Rodríguez, 2009).

De tal forma que, resulta necesario esclarecer que los convenios administrativos o interadministrativos, de cooperación o de asociación, no se rigen por el Estatuto de Contratación Estatal, "pues éstos son una modalidad alternativa de contratación que poseen las entidades estatales, pero que se rigen por normatividad especial" (Melo, Contratación estatal. Manual 
teórico-práctico, 2012). Respecto de éstos últimos, se tiene entonces que cuentan con una normatividad especial, cuya norma rectora es la Ley 489 de 1998, en la cual se establece la posibilidad de asociación entre entidades públicas y privadas, con el fin de cooperar hacia el cumplimiento de funciones administrativas o prestación conjunta de servicios que se hallen a su cargo (Artículos. 95 y 96).

No obstante, a simple vista los convenios y contratos resultan similares, pues ambos constituyen "un acuerdo de voluntades que crea obligaciones para las partes"(Melo, Contratación estatal. Manual teórico-práctico, 2012), pero se diferencian en algunos aspectos que hacen que su naturaleza sea distinta. Estos aspectos son, principalmente, que a diferencia de los contratos, los convenios se tramitan directamente; por ende, se prohíbe pactar y hacer exigible cláusulas exorbitantes ya que por su naturaleza éstos se celebran entre entidades públicas. Es así como en los convenios, por su naturaleza, las partes tienen y hacen aportes para un propósito común, para el cual cada uno aporta lo necesario para su cumplimiento y ninguna de las partes se dirige a obtener un mayor beneficio que el de cumplir una misión conjuntamente. Caso contrario ocurre con el contrato, el cual siempre tiene un contenido patrimonial; es decir, siempre se pacta un precio, honorario o recurso a favor del contratista, (Concepto 041-02271-2008 Procuraduría General de la Nación).

Finalmente, respecto a la naturaleza de los convenios celebrados con Organismos de Cooperación Internacional, podrían enmarcarse como contratos de la administración de derecho internacional privado entre sujetos de derecho internacional público, con una reglamentación especial de acuerdo a las disposiciones que van a regular el contrato o convenio entre los Organismos de Cooperación Internacionales y el Estado Colombiano en cuanto al porcentaje de los recursos destinados para la ejecución del mismo, y en la atención a que su objeto sea el de prestar meramente cooperación técnica (Ramos Venegas, 2009).

Por dichas razones, en términos de contratación con organismos internacionales se hace referencia a convenio, pues es a través de este acuerdo de voluntades que se cumple con los fines Constitucionales y Legales que les compete a las entidades estatales, cuya particularidad es ser un 
convenio de cooperación con una persona de carácter internacional, esto con el fin de buscar un aporte que de acuerdo a su experiencia y buenas prácticas vaya en pro del desarrollo del país.

\section{REGLAMENTACIÓN LEGAN EN COLOMBIA DELA CONTRATACIÓN CON ORGANISMOS DE COOPERACIÓN INTERNACIONAL.}

Es acertado mencionar que, en Colombia no existe un único documento que logre recopilar la normatividad existente en materia de Cooperación Internacional, de hecho, la podemos encontrar dispersa en preceptos de orden constitucional, del estatuto de contratación estatal y algunas leyes o decretos reglamentarios que emite la Presidencia de la República y el Ministerio de Relaciones Exteriores. Por consiguiente, nos encontramos con los artículos 9, 226 y 227 de la Constitución Política; el Decreto 111 de 1996, que establece normas presupuestales para los convenios de cooperación internacional; el Decreto 4512 de 2011 mediante el cual se crea la Agencia Presidencial de Cooperación Internacional de Colombia- APC; el Decreto 2170 de 2002 que preveía las reglas en la celebración con organismos internacionales para la administración de recursos (derogada); el Decreto 186 de 2004 derogado por el 2166 de 2004, que reglamentó parcialmente el derogado artículo 13 de la Ley 80 en cuanto a la contratación con organismos de cooperación internacional; los decretos 788 de 2002 y 540 de 2004 que disponen exenciones tributarias a los organismos en el marco de la cooperación internacional; el artículo 20 de la ley 1150 de 2007; los convenios marco de cooperación y los principios orientadores de la cooperación internacional.

La contratación con Organismos Internacionales de cooperación en Colombia se estableció como modalidad de contratación desde la creación del Estatuto General de Contratación Pública - Ley 80 de 1993, artículo 13 inciso $4^{\circ}$ - esta norma en su momento expresó de manera general que los "Los contratos financiados con fondos de los organismos multilaterales de crédito o celebrados con personas extranjeras de derecho público u organismos de cooperación, asistencia o ayuda internacionales, podrán someterse a los reglamentos de tales entidades en todo lo relacionado con procedimientos de formación y adjudicación y cláusulas especiales de ejecución, cumplimiento, pago y ajustes". 
Posteriormente, en el año 2004, a raíz de una demanda de inconstitucionalidad, mediante Sentencia C- 249 del 16 de marzo la Corte Constitucional se pronunció sobre la aplicación de las normas previstas para la contratación de tales organismos. La providencia expresa que cuando estos convenios eran celebrados en el territorio nacional, se estaría violando lo dispuesto en el artículo 4 constitucional, en tanto éste dispone que todas las personas residentes en Colombia, nacionales o extranjeras, públicas o privadas, están sometidas a la Constitución y a la Ley Colombianas, salvo los casos expresamente exceptuados por el ordenamiento superior. Esta situación que fue aclarada por la Corte Constitucional argumentando el cumplimiento de los tratados internacionales en acatamiento del Derecho Internacional.

A su vez, y como complemento a este tema, la Corte declaró la exequibilidad del inciso cuarto del artículo 13 de la Ley 80 de 1993, "en el entendido de que la discrecionalidad allí prevista sólo puede ejercerse válidamente, en relación con los contratos relativos a recursos percibidos de entes u organismos internacionales, esto es, en relación con contratos de empréstito, donación, asistencia técnica o cooperación celebrados por las respectivas entidades estatales con entes u organismos internacionales.(Sentencia C- 249 Corte Constitucional, 2004). Por consiguiente y con ocasión del pronunciamiento de la Corte Constitucional, el 21 de mayo de 2004 la Procuraduría General de la Nación a través la directiva 10 fijo criterios de aplicación de la sentencia C- 249 de 2004 en relación con la contratación con organismos internacionales, donde manifestó que el mencionado fallo determinó que el inciso final del artículo 13 de la Ley 80 de 1993, según el cual las entidades estatales podrán someterse a los reglamentos de los organismos internacionales en todo lo relacionado con procedimientos de formación y adjudicación y cláusulas especiales de ejecución, cumplimiento, pago y ajustes no era aplicable en relación con aquellos contratos relativos a recursos del presupuesto General de la Nación o de los presupuestos territoriales, cuando tales recursos no correspondan a donaciones o empréstitos.

De este modo, concluyó que todo convenio o contrato celebrado entre entidades y organismos internacionales a ejecutarse en el territorio colombiano con aportes de dineros públicos, sin importar el porcentaje del mismo, ha de sujetarse a los principios y normas de la Ley 80 de 1993. En consecuencia, las entidades públicas no podrán en este evento, someterse a 
los reglamentos de contratación de tales entidades, en todo lo relacionado con los procedimientos de formación, adjudicación y cláusulas especiales de ejecución, pago y ajustes.

Aunado a lo anterior, el 10 de junio de 2004 el Gobierno Nacional expidió el Decreto 1896 de 2004 que reglamentó el artículo 13 de la Ley 80 de 1993 expresando que "solamente los convenios o contratos financiados con fondos de los organismos multilaterales de crédito, o con recursos provenientes de donación o cooperación internacional de estos organismos, de personas extranjeras de derecho público u organismos de cooperación, asistencia, o ayuda internacionales, podrán someterse a los reglamentos de tales entidades en todo lo relacionado con procedimientos de formación y adjudicación y cláusulas especiales de ejecución, cumplimiento, pago y ajustes. "El mismo tratamiento se dará a los contratos o convenios financiados con recursos de contrapartida vinculados a estas operaciones".

Posteriormente, el 7 de julio de 2004, el Gobierno expidió el Decreto 2166 de 2004 que modificó el Decreto 1896 de 2004 y reglamentó parcialmente el artículo 13 de la Ley 80 de 1993, incluyendo el siguiente parágrafo: No se entenderán como contratos o convenios de cooperación y asistencia técnica internacional aquellos cuyo objeto sea la administración de recursos.

De otra parte, en razón a lo previsto en el Decreto 2166 de 2004, hubo lugar a derogar el artículo 15 del Decreto 2170 de 2002 que "preveía la administración de recursos públicos, por parte de los organismos de cooperación, asistencia o ayuda internacional de que trata el inciso final del artículo 13 de la ley 80 de 1993”, el cual fue declarado nulo por el Honorable Consejo de Estado por ser considerada una mala práctica por parte de la entidades estatales.

El 16 de julio de 2007 fue promulgada la ley 1150 que modificó integralmente el artículo 13 de la Ley 80 de 1993, recogiendo lo manifestado por la Corte Constitucional y la Procuraduría General de la Nación respecto de la contratación con organismos internacionales. De este modo, su artículo 20 expresó que:

"Los contratos o convenios financiados en su totalidad o en sumas iguales o superiores al cincuenta por ciento (50\%) con fondos de los organismos de cooperación, asistencia o 
ayudas internacionales, podrán someterse a los reglamentos de tales entidades. En caso contrario, se someterán a los procedimientos establecidos en la Ley 80 de 1993. Los recursos de contrapartida vinculados a estas operaciones podrán tener el mismo tratamiento.

Los contratos o convenios celebrados con personas extranjeras de derecho público u organismos de derecho internacional cuyo objeto sea el desarrollo de programas de promoción, prevención y atención en salud; contratos y convenios necesarios para la operación de la OIT; contratos y convenios que se ejecuten en desarrollo del sistema integrado de monitoreo de cultivos ilícitos; contratos y convenios para la operación del programa mundial de alimentos; contratos y convenios para el desarrollo de programas de apoyo educativo a población desplazada y vulnerable adelantados por la Unesco y la OIM; los contratos o convenios financiados con fondos de los organismos multilaterales de crédito y entes gubernamentales extranjeros, podrán someterse a los reglamentos de tales entidades.

Las entidades estatales no podrán celebrar contratos o convenios para la administración o gerencia de sus recursos propios o de aquellos que les asignen los presupuestos públicos, con organismos de cooperación, asistencia o ayuda internacional.

Parágrafo $1^{\circ}$. Los contratos o acuerdos celebrados con personas extranjeras de derecho público, podrán someterse a las reglas de tales organismos.

Parágrafo $2^{\circ}$. Las entidades estatales tendrán la obligación de reportar la información a los organismos de control y al Secop relativa a la ejecución de los contratos a los que se refiere el presente artículo.

Parágrafo $3^{\circ}$. En todo Proyecto de cooperación que involucre recursos estatales se deberán cuantificar en moneda nacional, los aportes en especie de la entidad, organización o persona cooperante, así como los del ente nacional colombiano. Las contralorías ejercerán el control fiscal sobre los proyectos y contratos celebrados con organismos multilaterales". 
De lo anterior, se puede concluir que con la Ley 1150 de 2007 se quiso recoger y precisar apartes que contemplaban algunas normas, decretos y lo dicho por la jurisprudencia sobre el tema de la contratación con organismos de cooperación internacional, donde el principal cambio fue el de no permitir la administración de recursos por parte de estos entes y colocar un límite mínimo de porcentaje del aporte dado por el ente internacional para poder someterse a sus reglamentos.

En el año 2013, el Gobierno Nacional expide el Decreto reglamentario 1510, que en su artículo $157^{4}$, además de exponer lo expresado en el artículo 20 de la ley 1150 de 2007, quiso poner un poco más de controles, por lo que además estableció que si los aportes del convenio son modificados, es decir que si los recursos públicos superan el $50 \%$ o si los mismos no se ejecutan

\footnotetext{
${ }^{4}$ Artículo 157. Régimen aplicable a los Contratos o Convenios de Cooperación Internacional. Los contratos o convenios financiados en su totalidad o en sumas iguales o superiores al cincuenta por ciento $(50 \%)$ con fondos de los organismos de cooperación, asistencia o ayudas internacionales, pueden someterse a los reglamentos de tales entidades incluidos los recursos de aporte de fuente nacional o sus equivalentes vinculados a estas operaciones en los acuerdos celebrados, o sus reglamentos, según el caso. En caso contrario, los contratos o convenios que se celebren en su totalidad o en sumas iguales o superiores al cincuenta por ciento $(50 \%)$ con recursos de origen nacional se someterán al presente decreto.

$\mathrm{Si}$ el aporte de fuente nacional o internacional de un contrato o convenio de Cooperación Internacional es modificado o los aportes no se ejecutan en los términos pactados, las Entidades Estatales deben modificar los contratos o convenios para efectos de que estos estén sujetos a las normas del sistema de compras y contratación pública, si el aporte de recursos públicos es superior al cincuenta por ciento (50\%) del total o de las normas internas de la entidad de cooperación si el aporte es inferior.

Cuando la variación de la participación de los aportes de las partes es consecuencia de las fluctuaciones de la tasa de cambio de la moneda pactada en el convenio o contrato de cooperación internacional, este seguirá sometido a las reglas establecidas en el momento de su suscripción.

Los recursos generados en desarrollo de los contratos o convenios financiados con fondos de los organismos de cooperación, asistencia o ayudas internacionales no deben ser tenidos en cuenta para determinar los porcentajes de los aportes de las partes.

Los contratos o convenios financiados con fondos de los organismos multilaterales de crédito, entes gubernamentales extranjeros o personas extranjeras de derecho público, así como aquellos a los que se refiere el inciso $2^{\circ}$ del artículo 20 de la Ley 1150 de 2007, se ejecutarán de conformidad con lo establecido en los tratados internacionales marco y complementarios, y en los convenios celebrados, o sus reglamentos, según sea el caso, incluidos los recursos de aporte de fuente nacional o sus equivalentes vinculados a tales operaciones en dichos documentos, sin que a ellos le sea aplicable el porcentaje señalado en el inciso primero del artículo 20 de la Ley 1150 de 2007.
}

Los contratos con personas extranjeras de derecho público se deben celebrar y ejecutar según se acuerde entre las partes. 
en los términos pactados, las Entidades deberán modificar estos convenios para que se sujeten al Estatuto de Contratación.

Así mismo, dispuso que cuando exista variación de los aportes por la fluctuación de la moneda, el convenio se seguirá rigiendo por las reglas establecidas al momento de su suscripción, y a su vez prescribe que los rendimientos financieros que se generen en marco de estos convenios, se tomaran en cuenta para establecer el monto de los aportes de las partes.

Posteriormente, el Gobierno Nacional el 26 de mayo de 2015 expide el decreto 1082, "Por medio del cual se expide el decreto único reglamentario del sector administrativo de planeación nacional”,, el cual en su Artículo 2.2.1.2.4.4.1. Régimen aplicable a los contratos o convenios de cooperación Internacional, recoge lo ya expresado por el artículo 157 del Decreto 1510 de 2013, este último derogado.

Ahora bien, pese a la normatividad ya expuesta, la Presidencia de la República en el año 2011 mediante el Decreto 4152 del 3 de noviembre creó la Agencia Presidencial de Cooperación Internacional de Colombia APC - COLOMBIA, cuyo objetivo es gestionar, orientar y coordinar la cooperación internacional pública, privada, técnica y financiera no reembolsable que reciba y otorgue el país; así como ejecutar, administrar y apoyar la canalización y ejecución de recursos, programas y proyectos de cooperación. A raíz de la creación de esta Agencia, mediante la Directiva Presidencial 02 de febrero de 2012, se indicó a las distintas entidades que componen el Gobierno Nacional que para fortalecer el conocimiento de la cooperación internacional que actualmente se desarrolla en el país, la APC COLOMBIA deberá consolidar un inventario de las gestiones de cooperación en curso que adelanten las entidades destinatarias de la directiva y recibirá de las mismas, en un plazo que no podrá superar el 11 de mayo de 2012, la información necesaria en el formato que para el efecto adopte la APC COLOMBIA.

Según la Agencia Presidencial para la Cooperación Internacional APC, para que la gestión de Cooperación Internacional sea efectiva y obtenga el impacto deseado, se requieren proyectos integrales, de calidad, bien formulados y alineados con las prioridades del país. Lo anterior implica que la formulación y ejecución de los proyectos se hagan a partir del cumplimiento de las condiciones y criterios de la CI, con adecuada planificación y participación de los beneficiarios y con claras probabilidades de incidir en la realidad que se pretende mejorar. 
APC-Colombia presta asesoría en la formulación, promoción y gestión de programas y proyectos de CI, con origen o destinada a diferentes agentes y en diversas modalidades; brinda también herramientas como el Manual de Formulación de Proyectos.

La APC enfatiza los siguientes criterios de viabilidad para los proyectos así:

i) Transferencia: Los proyectos deben permitir o facilitar la transferencia de conocimientos, tecnologías o experiencias de otros países hacia Colombia. No es recomendable recurrir a la cooperación internacional cuando en nuestro país hay fortaleza o capacidad en el tema para el que se busca apoyo.

ii) Un proyecto, además de ser el vehículo para recibir y apropiar tecnología de punta, debe estar concebido como un catalizador nacional de procesos de desarrollo.

iii) Creación de capacidades nacionales La filosofía de la cooperación internacional es brindar asistencia y capacidad técnica en áreas en las que el país receptor no tiene suficiente conocimiento o experiencia.

iv) Los proyectos de cooperación deben ser diseñados con el fin de obtener e incorporar nuevos conocimientos y construir con ello capacidad nacional, tanto en calificación de recursos humanos como en fortalecimiento institucional. Complementariedad de esfuerzos Los proyectos de cooperación internacional deben ser complementarios de los recursos técnicos y financieros del país.

v) No pueden estar concebidos como sustitución de aquellas tareas que las entidades deben y pueden atender, ni para llenar vacíos presupuestales. Por otra parte, es importante que exista un aporte de recursos de los países participantes. Por ello deben tener recursos de contrapartida nacional aportados por las entidades receptoras de la cooperación.

La Agencia Presidencial de Cooperación Internacional de Colombia APC fue creada para gestionar, orientar y coordinar la cooperación internacional pública, privada, técnica y financiera no reembolsable que reciba y otorgue el país; así como ejecutar, administrar y apoyar la canalización y ejecución de recursos, programas y proyectos de cooperación. 
A manera de conclusión, una vez visto el avance normativo en esta materia, si bien es cierto que hoy en día existe la APC, las entidades no siguen con rigurosidad los criterios establecidos para la viabilidad de los proyectos de cooperación, además de que no existe norma legal que obligue a la entidades estatales a presentar previamente a consideración de esta agencia los convenios que pretenden celebrar con organismos internacionales, pues las entidades actúan de manera independiente amparados en el artículo 20 de la ley 1150 de 2007, y celebran convenios de cooperación internacional excesivamente onerosos, con objetos que bien podrían desarrollarse por empresas nacionales y que en la práctica terminan ejecutando empresas nacionales, que carecen de componente internacional, que se utilizan para establecer nominas paralelas y algunos, a pesar de la prohibición legal, siguen administrando recursos públicos a través de esta práctica contractual.

\section{CONCLUSIONES}

Primera: La contratación estatal en Colombia es un mecanismo que tiene el Estado, a través de la Administración, para cumplir con sus fines esenciales y para garantizar la satisfacción de las necesidades públicas que se presenten, a través de procesos de selección con la participación de los ciudadanos. Presenta variedad de normas, leyes, decretos y pronunciamientos con serios vacíos que muchas veces llevan a interpretaciones erróneas por parte de las Entidades Contratantes, que afectan la actividad contractual.

Segunda: La cooperación internacional nace del Derecho Internacional y comprende diversas acciones que realizan actores públicos o privados con el propósito de promover el progreso económico en países de menor renta relativa comúnmente denominados "países del sur" o países en vías de desarrollo".

Tercera: El fin último de los organismos de cooperación internacional, de acuerdo a su naturaleza, es que los convenios que suscriben conlleven una verdadera cooperación a través del aporte internacional, que se encamine al desarrollo social y económico del país en el que cooperan, y Colombia ha sido una gran beneficiado de la cooperación internacional a través de convenios de cooperación con estas organizaciones. 
Cuarta: Vemos que las problemáticas en la contratación estatal en Colombia, conllevan a que la contratación con organismos internacionales de cooperación se utilice de manera equivocada, y en ocasiones adelantada por algunas entidades públicas únicamente como una salida rápida frente a la falta de planeación de su actividad contractual y pasar por alto las modalidades de selección de contratistas previstas en el Estatuto General de Contratación.

Quinta: La falta de planeación y el principio de anualidad, como problemáticas de la contratación estatal en Colombia, son las causas más comunes por la cuales la Entidades Estatales evaden los procesos de selección participativos y acuden con regularidad la utilización de la excepcionalidad de contratación directa a través de la celebración de convenios de cooperación internacional.

Sexta: Si bien hay regulación para la celebración de convenios con organismos de cooperación internacional en Colombia, las entidades abusan de esta, pues a través de estos convenios y en razón a que los mismos se rigen por los reglamentos del organismo internacional, terminan realizando contrataciones apresuradas, muy onerosas y sin una planeación seria y eficaz, que en nada demuestran que aporten al desarrollo del país. 


\section{LA CONTRATACIÓN CON ORGANISMOS INTERNACIONALES EN EL MINISTERIO DE EDUCACIÓN NACIONAL DURANTE LOS ÚLTIMOS DIEZ AÑOS}

\section{RESUMEN}

Este capítulo tiene como fin analizar la contratación del Ministerio de Educación Nacional con organismos de cooperación internacional durante los últimos diez años, esto con el propósito de determinar si los convenios celebrados conllevan el aporte internacional que por su naturaleza debe existir.

A su vez, se realizará un análisis estadístico sobre las cifras de los montos presupuestales anuales asignados al Ministerio de Educación Nacional, y si estos fueron invertidos en la celebración de convenios con organismos de cooperación internacional durante el lapso mencionado.

De igual forma, se establecerá si con la celebración de estos convenios llamados de Cooperación Internacional, la entidad de alguna forma pudo evadir los procesos y procedimientos de selección de contratistas establecidos en el Estatuto de Contratación Estatal (ley 80 de 1993), aplicables a la Entidades Estatales.

Por último, se determinará si a través de estos convenios se pudieron establecer casos de nóminas paralelas y, además, si algunos objetos de los convenios suscritos pudieron haber sido desarrollados por contratistas Colombianos.

Palabras clave: Ministerio de Educación Nacional, Cooperación Internacional, Presupuesto, Nominas Paralelas, Organismos Internacionales, Convenios Internacionales, Inmunidad Diplomática. 


\begin{abstract}
This paper aims to analyze the procurement of the Ministry of Education with international aid organizations during the past ten years, in order to determine whether the agreements concluded involve the international contribution, which by their nature must exist.

In turn, a statistical analysis of the figures of the annual budget amounts allocated to the Ministry of National Education will be held, determining thereof which was invested in the conclusion of agreements with international aid organizations during the period aforementioned time. .
\end{abstract}

Similarly, it is established whether the conclusion of these agreements called for International Cooperation, the organization turned somehow evading the processes and procedures for selecting contractors established in the Statute of State Procurement (Law 80 of 1993), applicable to the State entities.

Finally, it is determined whether through these agreements could establish cases of parallel payroll, and in turn, whether some of the agreements signed Colombian contractors may have developed objects.

Key words: Ministry of national education, international cooperation, budget, payroll parallel, international organizations, international conventions, diplomatic immunity 


\section{INTRODUCCIÓN}

A través del presente capítulo, se hará un breve recuento sobre la creación, naturaleza y fines del Ministerio de Educación Nacional en adelante MEN. De igual forma, se darán a conocer las cifras sobre el presupuesto anual asignado a esta entidad durante los últimos diez años, con el propósito de conocer cuál fue el porcentaje de destinación del mismo en la celebración de convenios con organismos de cooperación internacional. Además, se establecerán los principales motivos por los cuales frecuentemente algunas entidades estatales, entre ellas el Ministerio de Educación Nacional, acuden a esta clase de contrataciones.

Asimismo, se realizará un breve análisis, sobre algunos convenios celebrados con organismos en el Ministerio de Educación Nacional con el fin conocer si realmente existió aporte internacional en pro del desarrollo de nuestro país; o simplemente, se dieron como resultado de la falta de planeación de la Entidad y no acatamiento del Estatuto de Contratación Estatal. Este análisis permitirá determinar la eficiencia y validez de la contratación estatal con organismos internacionales en Colombia. Lo anterior, a través de una metodología de trabajo de campo que nos permitirá estudiar los presupuestos y el número de convenios suscritos, y realizar una crítica sobre los aportes de estos convenios al desarrollo de la educación del país. ${ }^{5}$

Por último, se analizará la contratación con organismos internacionales en Uruguay, por contar con un sistema de contratación ajustado a la cooperación internacional, que ha servido de modelo para la contratación con organismos internacionales que se adelanta actualmente en Colombia.

\section{EL MINISTERIO DE EDUCACIÓN NACIONAL}

En primer lugar entraremos a referirnos al concepto de Ministerio, si bien la ley no lo define, la Real Academia Española en términos generales define Ministerio como "Cada uno de

\footnotetext{
5 Este trabajo de campo fue posible gracias a la radicación de diversos derechos de petición, además de la experiencia
} de la investigadora en la entidad. 
los departamentos en que se divide la gobernación del Estado" (Real Academia Española). Así las cosas, podría afirmarse que el concepto anteriormente mencionado se enfatiza en la división de funciones de un Gobierno, esto es, una parte funcional del Estado, a través de la cual se designan una serie de funciones a quien lo encabeza. En este sentido, es viable afirmar que, "los Ministerios son los organismos de la administración nacional central que siguen en importancia a la Presidencia de la República y que están encargados de dirigir, coordinar y ejecutar un conjunto de servicios públicos". (Rodriguez, 1994)

En consecuencia, el Ministerio de Educación Nacional, acorde con lo previsto en el Decreto No. 5012 de 2009, es un organismo y/o departamento encargado, entre otros objetivos y funciones, de establecer las políticas y lineamientos para dotar al sector educativo de un servicios de calidad con acceso equitativo y con permanencia en el sistema ${ }^{6}$.

\section{A. Fines}

El Ministerio de Educación Nacional en Colombia tiene como fines, principalmente: (i) lograr una educación de calidad, que forme mejores seres humanos, ciudadanos con valores éticos, competentes, respetuosos de lo público, que ejercen los derechos humanos, cumplen con sus deberes y conviven en paz; (ii) una educación que genere oportunidades legítimas de progreso y prosperidad para el país; (iii) lograr una educación competitiva, pertinente, que contribuya a cerrar brechas de inequidad y en la que participe toda la sociedad. (http://www.mineducacion.gov.co/1621/w3-channel.html)

Para lograr los fines propuestos, el Ministerio de Educación debe cumplir, entre otras, las siguientes funciones: (i) formular la política nacional de educación; (ii) "Preparar y proponer los planes de desarrollo del Sector, en especial el Plan Nacional de Desarrollo Educativo; (iii) dictar las normas para la organización y los criterios pedagógicos y técnicos para la atención integral a la primera infancia y las diferentes modalidades de prestación del servicio educativo; (iv) asesorar a los Departamentos, Municipios y Distritos en los aspectos relacionados con la educación; (v) impulsar, coordinar y financiar programas nacionales de mejoramiento educativo

\footnotetext{
${ }^{6}$ Articulo 1 Decreto 5012 de 2009 expedido por el Ministerio de Educación Nacional.
} 
que se determinen en el Plan Nacional de Desarrollo entre otras" (Ministerio de Educación Nacional, 2015).

Como consecuencia de lo anterior, el Ministerio de Educación Nacional se ve muy abocado a la celebración de convenios con organismos de cooperación internacional, dado que la educación es uno de los primordiales pilares del progreso y desarrollo de cualquier país.

\section{B. Creación y Naturaleza Jurídica}

El Ministerio de Educación Nacional fue creado mediante la Ley $7^{\text {a }}$ de agosto 25 de 1886. Anteriormente, se denominó Secretaría de Instrucción Pública (Ley 10ª de 1880) que reemplazó a la Secretaría del Exterior (Ministerio de Gobierno) que antes de 1880 atendía los asuntos educativos. En junio de 1923, cambia el nombre de Ministerio de Instrucción Pública por el de Ministerio de Instrucción y Salubridad Públicas y desde el $1^{\circ}$ de enero de 1928 se le identifica con el nombre de Ministerio de Educación Nacional, según lo dispuso la Ley 56 de 1927.

El Ministerio de Educación Nacional es una entidad del orden nacional, del nivel central, creada por ley, que hace parte de la Rama Ejecutiva del Poder Público, y que para los efectos de la Ley 80 de 1993 se denomina como entidad estatal conforme a su artículo 2, literal b.

\section{Presupuesto}

Para el cumplimiento de los fines y metas de las entidades estatales del nivel central, el Estado asigna ciertas sumas de dinero que se convierten en su presupuesto, el cual por lo general se asigna anualmente.

Según RESTREPO, el presupuesto se considera como un instrumento de gobierno y de control en las sociedades democráticas, ya que es una expresión de la separación de poderes y una natural consecuencia del sometimiento del Gobierno a la ley. (Restrepo, 2005). Además, el presupuesto enmarca toda la práctica de política fiscal del Estado, por medio de éste se llevan a 
cabo la búsqueda y el cumplimiento de principios y finalidades de la actuación administrativa para la satisfacción de necesidades de los individuos y se garantizan los recursos necesarios para el normal funcionamiento del aparato estatal (Welsch, 2005).

Para BARRA, el presupuesto se debe a una definición política, es una pieza fundamental de las decisiones de un Estado, pues ya no se llega a concebir al presupuesto como una previsión contable de los ingresos y gastos del Estado, donde el principio del equilibrio tenía una importancia fundamental, sino como un instrumento de regulación de la actividad económica del país en su conjunto (Barra, 2011).

De otra parte, y según conceptos jurídicos del Ministerio de Hacienda de Colombia el presupuesto público cumple un importante papel en la ejecución de la política económica del Estado, por lo que la calidad de su formulación es un elemento determinante para garantizar la sostenibilidad fiscal. Por esta razón, lo presupuestal ocupa un papel destacado en el ordenamiento jurídico del país, lo cual se ha materializado en las disposiciones presentes en la Constitución Política de 1991, en el Estatuto Orgánico del Presupuesto (EOP), en sus normas reglamentarias, en la jurisprudencia y en la doctrina, que, en conjunto, configuran las fuentes de derecho en esta materia. (Ministerio de Hacienda y Crédito Público, 2011)

Aunado a lo anterior, una de las principales características del presupuesto de gastos es la Anualidad, pues este presupuesto tiene vigencia de un año. Por consiguiente, debe ser ejecutado dentro del año fiscal que comienza el primero de enero y culmina el 31 de diciembre. Después de esa fecha no se puede adquirir ningún compromiso con cargo al presupuesto que se cierra (Peña Gonzalez, 2007).

De lo anterior y una vez comprendido el significado del presupuesto para un Estado, es importante señalar que en Colombia el manejo y distribución del mismo se encuentra en cabeza del Ministerio de Hacienda y Crédito Público, que es el encargado de su distribución, conforme al plan de desarrollo del País. 
Por su parte, la distribución del presupuesto general de la Nación, se realiza en primer orden a las entidades del Orden Nacional, para el desarrollo y cumplimiento de sus fines y metas, entre las cuales se encuentran los Ministerios, siendo el Ministerio de Educación Nacional uno de los que más presupuesto se le asigna, y el cual cada año se incrementa. (Rosas, M., Fuentes, L., Quintero D. 2010).

\section{Análisis estadístico sobre el presupuesto asignado al MEN destinado a Contratación con organismos internacionales}

De acuerdo a lo anterior, veremos en el siguiente cuadro, el análisis de la totalidad del presupuesto asignado al Ministerio de Educación Nacional en la última década, con el fin de conocer la suma de recursos de cada vigencia destinados a la contratación con Organismos de Cooperación Internacional.

\begin{tabular}{|c|c|c|c|c|}
\hline $\begin{array}{l}\text { PRESUPUE } \\
\text { VIGENCIA }\end{array}$ & O ASIGNADO POR & $\begin{array}{|lr|}\text { PRESPUESTO } & \\
\text { DESTINADO } & \text { A } \\
\text { CONTRATACIÓN } & \text { CON } \\
\text { ORGANISMOS } & \text { DE } \\
\text { COOPERACIÓN } & \\
\text { INTERNACIONAL } & \\
\end{array}$ & \begin{tabular}{|lr} 
NÚMERO & APROXIMADO \\
DE & CONVENIOS \\
SUSCRITOS & \\
\end{tabular} & PORCENTAJE \\
\hline 2005 & 12.227 .236 .608 .830 & 10.049.139.391 & 16 & $0,08 \%$ \\
\hline 2006 & 13.123.076.293.928 & 8.557 .330 .440 & 7 & $0,07 \%$ \\
\hline 2007 & 14.211.462.944.558 & 4.301 .218 .440 & 10 & $0,03 \%$ \\
\hline 2008 & 16.187 .701 .658 .608 & 63.593 .701 .881 & 20 & $0,39 \%$ \\
\hline 2009 & 18.760 .177 .284 .490 & 82.210 .260 .057 & 23 & $0,44 \%$ \\
\hline 2010 & 20.817 .659 .815 .521 & 45.597.464.441 & 10 & $0,22 \%$ \\
\hline 2011 & 21.733.748.777.302 & 67.547.726.934 & 15 & $0,31 \%$ \\
\hline
\end{tabular}




\begin{tabular}{|l|c|c|c|c|}
$\mathbf{2 0 1 2}$ & 23.329 .695 .969 .271 & 89.626 .758 .347 & 16 & $0,38 \%$ \\
\hline $\mathbf{2 0 1 3}$ & 25.207 .541 .286 .484 & 34.556 .162 .129 & 20 & $0,14 \%$ \\
\hline $\mathbf{2 0 1 4}$ & 33.285 .627 .895 .409 & 10.006 .831 .351 & 9 & $0,03 \%$ \\
\hline
\end{tabular}

Como se puede apreciar el presupuesto del Ministerio de Educación Nacional durante los últimos diez años fue de \$ \$198.833.928.534.401., de los cuales se invirtieron en la celebración de convenios de cooperación la suma de \$ 416.046.593.411.oo, esto mediante la suscripción de 137 convenios de cooperación internacional.

Para mayor ilustración en la siguiente gráfica se refleja el presupuesto anual asignado al MEN, comparado con los recursos invertidos por esta Entidad en la celebración de convenios de cooperación con organismos internacionales.

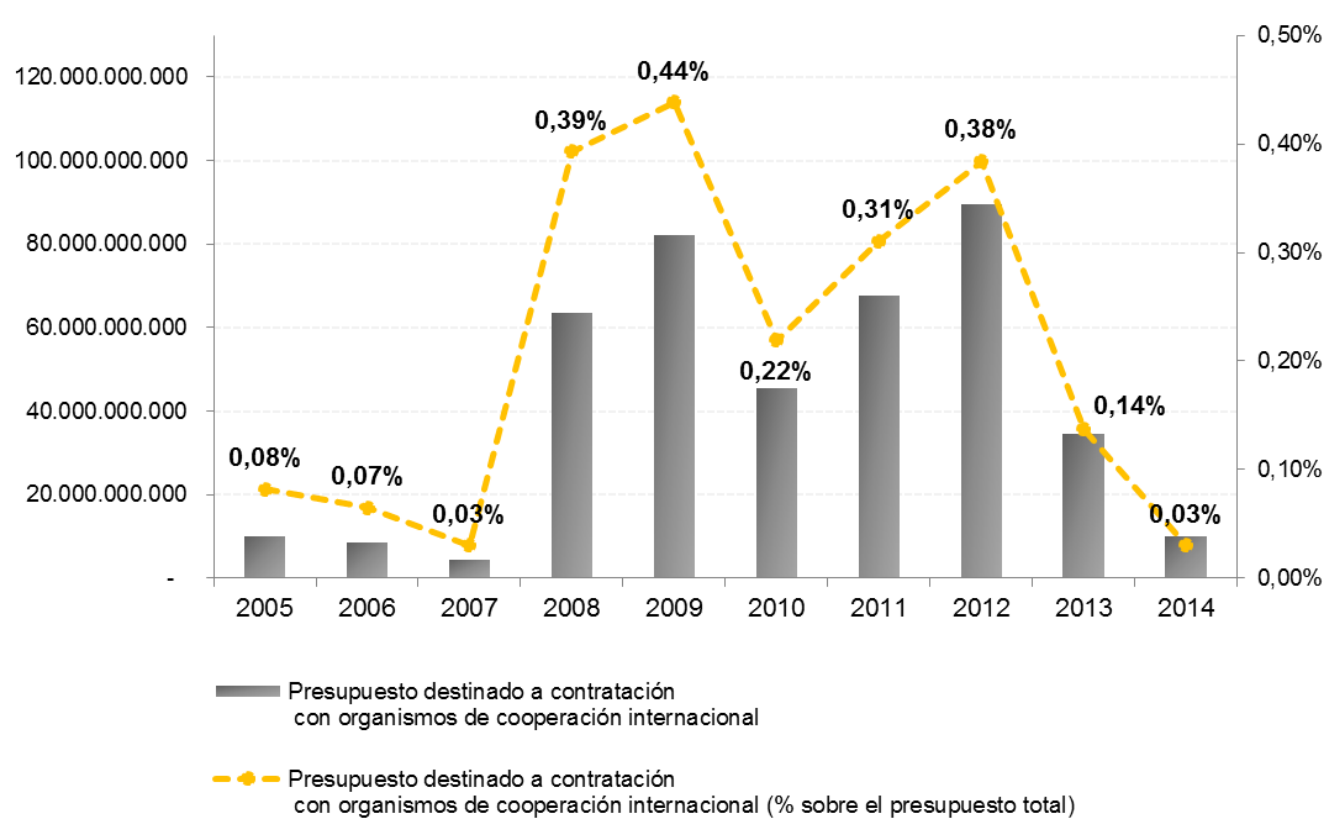


Vemos que los porcentajes sobre el presupuesto destinado a la contratación con organismos de cooperación internacional están por debajo del $1 \%$ del presupuesto total del Ministerio por cada vigencia anual, lo que lleva a concluir que la inversión en proyectos que propendan por el desarrollo social del país a través de la educación representó un mínimo porcentaje durante los últimos diez años, en lo que respecta al Ministerio de Educación Nacional de Colombia.

Como complemento del cuadro anterior, en documento anexo se relacionan los convenios de cooperación internacional que ha suscrito el Ministerio de Educación Nacional durante los últimos diez años, del cual se puede concluir que existen contrataciones recurrentes con organismos de cooperación, asistencia y ayuda técnica como la OEI, OIM por cifras significativas, algunos con objetos que al parecer no comprenden un verdadera cooperación internacional.

\section{PRINCIPALES MOTIVOS PARA LA CELEBRACIÓN DE CONVENIOS CON ORGANISMOS INTERNACIONALES EN COLOMBIA}

De conformidad con lo expuesto, es dable mencionar que la causa principal por la que las entidades estatales deciden celebrar convenios de cooperación con organismos internacionales es porque a través de dicha actividad negocial va a existir un aporte internacional que propenda en el desarrollo del país. Para el caso del Ministerio de Educación Nacional en el anexo se pueden apreciar varios convenios que han resultado ampliamente beneficios para el desarrollo de la educación en Colombia, pues con ellos se han alcanzado logros de calidad y cobertura en Educación.

Sin embargo, se observa que hay algunos convenios de cooperación internacional que se celebran, como último recurso por las Entidades estatales, frente a situaciones como por ejemplo, la falta de planeación, aplicación del principio de anualidad del gasto, no aplicación del estatuto de contratación y sometimiento a las normas de los entes internacionales, ejecución de recursos asignados con el fin de demostrar cumplimiento de metas, situaciones de las cuales el 
Ministerio de Educación Nacional no ha sido exenta frente a su actividad contractual en esta materia.

Así las cosas, es importante analizar a continuación cada una de estas situaciones:

\section{A. Falta de planeación}

Si bien la planeación es un principio de la actividad contractual, que va ligada al principio de economía, tal como lo ha dicho la Corte Constitucional "El principio de economía pretende que la actividad contractual "no sea el resultado de la improvisación y el desorden, sino que obedezca a una verdadera planeación para satisfacer necesidades de la comunidad" sin embargo, vemos que frecuentemente algunas Entidades Estatales no planean oportunamente sus contrataciones, situación que muchas veces conlleva a que no se logre ejecutar el presupuesto anual asignado y que trae como consecuencia sanciones por inejecución de recursos por parte del Ministerio de Hacienda (Sentencia C 15324, 2007).

De otro lado, y en razón a que la falta de planeación implica acudir frecuentemente a la contratación directa, mediante Circular Conjunta 14 de 2011, la Auditoría General de la República, la Contraloría General de la República y la Procuraduría General de la Nación, en cumplimiento de sus funciones realizaron hallazgos y advertencias, así:: i) se han diagnosticado que a menudo se acude a la contratación directa para eludir los procedimientos de selección acordes con la naturaleza de los bienes, obras o servicios que se pretenden adquirir o con su cuantía. ii) se ha encontrado también que se entregan importantes recursos del presupuesto estatal a particulares, sociedades de economía mixta, instituciones de educación superior y fundaciones, entre otros, que no resultan idóneos para ejecutar el objeto pactado, lo que impide que se satisfagan las necesidades que suscitaron el correspondiente negocio jurídico, exponiendo los intereses colectivos involucrados y iii) se les recuerda a las entidades la aplicación de los principios de transparencia, economía, responsabilidad, selección objetiva y los lineamientos generales para la utilización de esta modalidad de contratación, buscando evitar su aplicación indebida, así como la elusión de los procedimientos legales de contratación y, por tanto, la vulneración de la normatividad vigente y la pérdida de recursos del Estado. 
De lo anterior, podemos ver que la falta de planeación es una de las principales causas para que las entidades recurran a la contratación directa como modalidad de contratación excepcional con Organismos de Cooperación Internacional, que muchas veces resultan ser contrataciones como lo ha dicho la Corte que se alejan de los procesos de contratación y resultan vulnerando la normatividad. (Expósito Vélez, 2008)

\section{B. Anualidad del gasto}

De otra parte, podemos referirnos a un factor importante en contra de la buena ejecución de recursos en materia de contratación estatal por parte de las entidades estatales: el principio de anualidad del gasto público. La aplicación de este precepto normativo implica que las entidades ejecutoras del Presupuesto General de la Nación deben comprometer y ejecutar los recursos dentro de la vigencia para la cual les fueron asignados; es decir, en el término del año fiscal que comprende desde el 1 de enero de hasta el 31 de diciembre de cada año (Ley 38/89, artículo 10), plazo que muchas veces resulta corto para una buena ejecución de recursos, en especial, para entidades con presupuestos excesivamente altos y que requieren para su ejecución de multiplicidad de procesos de selección.

Ahora bien, en relación a lo anterior la Corte Constitucional ha expresado que en Colombia rige el principio de anualidad consagrado en el art. 346 de la $\mathrm{CP}$, modificado por el artículo 3 del Acto Legislativo 03 de 2011, que reza: "El Gobierno formulará anualmente el presupuesto de rentas y ley de apropiaciones, que será presentado al Congreso dentro de los primeros diez días de cada legislatura. El presupuesto de rentas y ley de apropiaciones deberá elaborarse, presentarse y aprobarse dentro de un marco de sostenibilidad fiscal y corresponder al Plan Nacional de Desarrollo., por lo cual una partida debe ser ejecutada o comprometida en el año fiscal respectivo, pues si ello no ocurre, la partida o los saldos de apropiación no afectados por compromisos inevitablemente expiran o caducan, de suerte que no podrán adquirirse compromisos con cargo a ella en los periodos fiscales posteriores". (Sentencia C 192, 1997)

A su vez, la ley permite que se ejecuten contratos en distintas vigencias, es decir abarcando más del año fiscal, para lo cual las Entidades pueden tramitar y justificar ante la 
Dirección General del Presupuesto Nacional del Ministerio de Hacienda y Crédito Público las correspondientes vigencias futuras y traslados presupuestales, con el fin de asumir obligaciones, que afecten presupuestos de próximas vigencias, cuando su ejecución se inicie con presupuesto de la vigencia en curso y el objeto del compromiso se lleve a cabo en cada una de ellas (Ley 179 de 1994, artículo 9). Sin embargo, las entidades estatales, por falta de una buena planeación, no solicitan los respectivos traslados presupuestales o las vigencias futuras que requieren para alcanzar los resultados de una buena y oportuna ejecución de recursos (Ministerio de Hacienda y Credito Público, 2011).

En ese orden de ideas, la restricción en la anualidad del gasto, conlleva a que las entidades en el afán de cumplir las metas presupuestales asignadas acudan frecuentemente a la contratación directa con los llamados Organismos de Cooperación Internacional.

\section{Sometimiento a las normas de los entes internacionales}

Por tratarse de una contratación de carácter especial permite que los convenios celebrados se rijan por las normas del Organismo Internacional, "normas que no se comparan con la rigurosidad de las previstas en el Estatuto General de Contratación de nuestro país, además que no existe límite en el monto presupuestal destinado en estas contrataciones". (Castro, García \& Martínez, 2010). Este es uno de los motivos por el cual las entidades públicas acuden con regularidad a la celebración de convenios de cooperación, pues en ellos se invierten grandes sumas de dinero, y de esta forma demuestran ejecución de los recursos asignados, aunque muchas veces lo hagan para desarrollar objetos que no compensan la cantidad de aportes invertidos.

De otra parte, según ESTRADA en cuanto a la excepcionalidad establecida en el Estatuto de Contratación Estatal en lo que se refiere a la contratación con organismos internacionales, que a buen juicio fue propuesta por el legislador, se ha extraviado su finalidad y por cuenta de su confusa redacción y de interpretación acomodadas se han convertido en un instrumento para evadir los procesos de selección. (Estrada Sánchez, 2009). 
De lo anterior, podemos concluir que algunas entidades optan por acudir a la celebración de convenios de cooperación internacional, por ser esta una contratación más ágil que se rige por los reglamentos del organismo internacional que en realidad son normas de derecho privado, y de esta forma evaden el adelantamiento de los procesos de selección y la aplicación del Estatuto de Contratación Estatal.

\section{Vinculación de personal a través de estos convenios}

Otro motivo para que se acuda a esta clase de contratación y que puede ser considerado una mala práctica, es la utilización de estos convenios de cooperación internacional para la vinculación de personal mediante contratación de prestación de servicios profesionales para desarrollar funciones propias de la entidad. En consecuencia, los honorarios de este personal son cubiertos con los aportes de la entidad contratante en el marco de un convenio de cooperación internacional, de esta forma, la entidad no demuestra tener una excesiva planta de personal, la cual les es restringida por motivos de austeridad del gasto; sin embargo, esta situación puede configurar las tan polémicas denominadas nominas paralelas.

$\mathrm{Al}$ respecto, ha dicho la Corte Constitucional que "A pesar de la prohibición de vincular mediante contratos de prestación de servicios a personas que desempeñan funciones permanentes en la administración pública, en la actualidad se ha implantado como práctica usual en las relaciones laborales con el Estado la reducción de las plantas de personal de las entidades públicas, el aumento de contratos de prestación de servicios para el desempeño de funciones permanentes de la administración y de lo que ahora es un concepto acuñado y públicamente reconocido: la suscripción de nóminas paralelas o designación de una gran cantidad de personas que trabajan durante largos períodos en las entidades públicas en forma directa o mediante las cooperativas de trabajadores, empresas de servicios temporales o los denominados outsoursing, situación que también sucede a través de convenios de cooperación internacional. (Sentencia C 614, 2009)

La razón por la cual las entidades utilizan estos convenios para vincular indirectamente personal, obedece a que de esta forma no demuestran aumento en su planta de personal, pues por 
austeridad del gasto público las entidades deben vincular personal estrictamente necesario y con funciones ya preestablecidas de acuerdo a la ley.

\section{E. Demostrar ejecución de recursos}

Según pronunciamiento de la Procuraduría Delegada para la Vigilancia Preventiva de la Función Pública, los recursos de un contrato estatal se entienden ejecutados una vez se reciba el bien o servicio contratado. No obstante, según concepto del Ministerio de Hacienda y Crédito Público, para los convenios de cooperación internacional, los recursos allí invertidos se entienden ejecutados con la mera suscripción y registro presupuestal del convenio, situación que favorece a las entidades estatales, pues estas deben demostrar la ejecución de recursos, para concluir que han hecho un buena gestión pública. (Ministerio de Hacienda y Crédito Público 2011).

De conformidad con lo expuesto, es importante precisar que la contratación con organismos internacionales de cooperación, en algunas ocasiones, es utilizada como último recurso por las entidades, principalmente: (i) ante la falta de planeación, pues no les da tiempo de adelantar los correspondientes procesos selección; (ii) cuando no tramitan o no tramitan en tiempo las correspondientes vigencias futuras y requieren invertir los recursos públicos que les fueron asignados en la vigencia fiscal correspondiente; (iii) para la inversión de gran cantidad de recursos, pues en estos convenios no existe límite del valor para sus celebración y (iv) además, porque con la suscripción del convenio los recursos allí destinados se entienden ejecutados, situación que favorece a la entidad estatal que los da en calidad de aporte.

\section{ORGANISMOS INTERNACIONES DE COOPERACIÓN ASISTENCIA O AYUDA CON LOS QUE CONTRATA EL MEN}

Ahora bien, con el fin de comprender mejor el análisis en desarrollo, es importante ver la clasificación de los Organismos internacionales, no sin antes recordar su definición. Para VALENCIA, estos organismos u organizaciones de cooperación internacional están dentro del grupo de organizaciones gubernamentales donde sus miembros son Estados, por lo que se rigen por el derecho internacional, esto implica que adquieren derechos y obligaciones bajo el sistema 
jurídico internacional. Además, estas organizaciones gubernamentales son diseñadas, creadas y usadas para alcanzar objetivos entre sí (Valencia Restrepo, 2008), con personería jurídica distinta a la de sus estados miembros.

Por otra parte, existen las organizaciones internacionales no gubernamentales (ONG), estas son "todo grupo, asociación o movimiento constituido de forma duradera por particulares pertenecientes a diferentes países, con la finalidad de alcanzar objetivos no lucrativos" (Merle, 1985); generalmente, se forman por individuos o grupos sociales de carácter particular y no estatal. Según VELLAS, su naturaleza jurídica se deriva del derecho interno (nacional) de los estados y no del derecho internacional público, pues "las ONG son organizaciones de derecho privado con vocación internacional” (Vellas, 1967).

Así las cosas, dentro de esta investigación nos enfocaremos en las organizaciones gubernamentales; específicamente, en los organismos internacionales de cooperación, asistencia o ayuda internacional, ya que son aquellas en lo que se enfoca el problema jurídico expuesto.

Por su parte, el artículo 20 de la más reciente reforma al Estatuto de Contratación Estatal adoptado mediante la Ley 1150 de 2007, describe de manera enunciativa los que serían los llamados Organismos de Cooperación Internacional, los cuales podemos diferenciar en tres clases: (i) Fondos multilaterales de crédito, (ii) Personas extranjeras de derecho público y (iii) Organismos de cooperación, asistencia o ayuda internacional.

En primer lugar, los fondos multilaterales de crédito son instituciones financieras conformadas por una serie de países interesados en promover la cooperación económica internacional y regional, con el fin de promover y mejorar las relaciones comerciales y brindar ayuda financiera encaminada a programas sociales, entre los que podemos mencionar, al Fondo Monetario Internacional FMI, el Banco Mundial - BM y el Banco Interamericano de DesarrolloBID. La cooperación con estas organizaciones, generalmente, se otorga mediante la entrega de recursos en dinero o en especie y es de carácter no reembolsable, en este caso podemos hablar de un contrato de donación. Por otra parte, dentro de las personas extranjeras de Derecho Público se encuentran los Ministerios y Entes Territoriales de países extranjeros; finalmente, los Organismos 
de Cooperación, Asistencia, o Ayuda Internacional prestan ayuda oficial dirigida a los países en vía de desarrollo por parte de los países avanzados o por organismos multilaterales de cooperación "norte - sur", aquí podemos encontrar a la Organización para la Cooperación y el Desarrollo Económico -OECD; la Organización de Estados Iberoamericanos- OEI, la Organización Mundial de las Migraciones -OIM, la Organización Mundial de la Salud -OMS, entre otros.

En este sentido, la cooperación con estas organizaciones se realiza a través de los contratos o convenios que se desarrollan y ejecutan bajo la voluntad de la fuente o según lo dispongan las partes, pues una de las exigencias más frecuentes es aplicar sus reglamentos y procedimientos en la ejecución de los recursos de cooperación que se entregan (Presidencia de la Republica, 2008). Ahora bien, en estos convenios de cooperación se establecen los principios, reglas y procedimientos a seguir para su celebración cuando se involucran recursos del ente internacional, esta disposición es de contenido particular y específico, con jerarquía de un compromiso internacional, se trata de una disposición de carácter especial que debe primar en su aplicación sobre la de carácter general (Estatuto de Contratación Estatal. (Zea de Durán, 2002).

En este punto es necesario realizar un énfasis en la contratación del MEN con organizaciones internacionales de cooperación, asistencia o ayuda internacional, pues es aquí donde se percibe el problema jurídico planteado.

No nos enfocaremos en la celebración de convenios con los organismos multilaterales de crédito, pues estos convenios no representan mayores críticas, ya que la mayoría de veces se hacen convenios de préstamo de dinero para ejecución de proyectos, que de acuerdo al éxito del mismo, algunas veces, resulta en una donación.

Como se mencionó en el capítulo que precede, los organismos u organizaciones de cooperación internacional fueron creados con el fin de que los países desarrollados presten ayuda y asistencia técnica a aquellos países menos desarrollados en temas económicos, culturales, sociales, educativos, entre otros. (Gutierrez Espada, 1995). De tal forma que, dentro de la 
contratación con organismos de cooperación internacional que adelanta en Ministerio de Educación Nacional, frecuentemente, acude a ciertos organismos, en atención a temas educativos.

De conformidad con lo anterior, el Ministerio de Educación realiza convenios con organismos como:

\section{A. La organización para la cooperación y el desarrollo económicos (OECD)}

La OECD fue fundada en 1961 y agrupa a 34 países miembros. Su misión es promover políticas que mejoren el bienestar económico y social de las personas alrededor del mundo (http://www.oecd.org/centrodemexico/laocde/).

\section{B. La Organización de las Naciones Unidas para la Educación, la Ciencia y la Cultura (UNESCO)}

La UNESCO fue fundada en 1945 por la Organización de las Naciones Unidas (ONU) y se encarga de apoyar la ejecución de proyectos nacionales; el desarrollo de programas y proyectos regionales; y el intercambio de experiencias e información en América Latina. Colombia ha recibido ayuda para ejecutar proyectos en temas como educación ambiental, educación en valores, educación para la paz, competencias ciudadanas, formación docente, alfabetización y aquellos dirigidos a la población con discapacidad y en desplazamiento ( http://www.unesco.org/new/es/unesco/about-us/.)

\section{La Organización de Estados Iberoamericanos (OEI)}

La OEI fue creada para la cooperación entre los países iberoamericanos en proyectos de educación, ciencia y cultura; alfabetización; derechos humanos; primera infancia; formación docente y evaluación educativa. Igualmente, ayuda a fortalecer la ayuda educativa a través de los foros, cursos, institutos de desarrollo e innovación educativa.

\section{El Convenio Andrés Bello (CAB)}


El CAB tiene como objetivo apoyar las áreas de educación, ciencia, tecnología y cultura a través del respaldo a la política educativa del país. Esto se manifiesta en proyectos de alfabetización, primera infancia, educación ambiental, formación docente, intercambio de experiencias, foros, evaluaciones, observatorios, investigaciones, publicaciones, calidad y pertinencia educativa. (http://convenioandresbello.org/inicio/blog/2014/08/14/un-primer-vistazoa-los-objetivos-de-desarrollo-sostenible/.

\section{E. El Fondo de Población de las Naciones Unidas (UNFPA)}

UNFPA es una agencia de cooperación internacional creada para el desarrollo, esta busca promover el derecho a una vida sana y en igualdad de oportunidades para todos. Se caracteriza por cooperar en temas de educación para la sexualidad, la construcción ciudadana y los derechos humanos. (http://www.cepal.org/12conferenciamujer/noticias/paginas/8/49918/Informe_UNFPALACRO_-_XII_CRM.pdf)

\section{F. La Organización internacional para las migraciones (OIM)}

La OIM fue fundada en 1951, se ocupa de la problemática de las migraciones. Por ende, trabaja en la búsqueda de soluciones humanas y prácticas para los migrantes que lo necesiten, como desplazados o personas desarraigadas. Todos los programas de la OIM involucran la perspectiva de género y se implementan con una visión integral y diferencial hacia la población indígena y afro-colombiana.

La OIM en Colombia es un aliado estratégico para los programas del Ministerio de Relaciones Exteriores, relacionados con la Política Integral Migratoria, en particular para la Coordinación de Colombia Nos Une, adscrita a la Dirección de Asuntos Migratorios, Consulares y de Servicio al Ciudadano. (http://www.cancilleria.gov.co/international/multilateral/intergovernmental/iom)

\section{G. EI Fondo de las Naciones Unidas para la Infancia-UNICEF}


El UNICEF es un programa de la Organización de las Naciones Unidas creado en 1946 que presta ayuda humanitaria y propende por la protección de los derechos de los niños y madres desprotegidos en países en desarrollo. La cooperación de la Unicef y el Ministerio de Educación MEN estuvo dirigida en un principio al fortalecimiento del programa escuela nueva, posteriormente, se centró en el trabajo con las regiones.

De lo anterior, se puede apreciar que estas instituciones de tipo internacional se enfocan en temas relacionados con el comercio internacional, las telecomunicaciones o las acciones humanitarias y en temas educativos, este último como componente primordial para el cumplimiento de los fines y metas que tiene el Ministerio de Educación de Colombia. Con ocasión a este componente educativo, el Ministerio de Educación ha suscrito diversos convenios de cooperación internacional, que han supuesto grandes beneficios para el la educación del país. No obstante, se demostrará que en un margen mínimo ciertos convenios de cooperación internacional celebrados por el Ministerio de Educación no tienen como prioridad el aporte internacional en materia de educación que propenda por el desarrollo del país, sino que su celebración muchas veces obedece a aspectos netamente procedimentales y presupuestales.

Además de los organismos mencionados, con los que de manera frecuente el MEN celebra convenios; existen otros con los que alguna vez suscribió convenios o lo hace esporádicamente, de los que se hace mención en documento anexo.

\section{ANÁLISIS DE CIERTOS CONVENIOS DE COOPERACIÓN INTERNACIONAL SIGNIFICATIVOS SUSCRITOS POR EL MINISTERIO DE EDUCACIÓN NACIONAL}

Como se mencionó anteriormente durante los últimos diez (10) años, el Ministerio de Educación Nacional ha suscrito alrededor de 137 convenios de cooperación con organizaciones de cooperación internacional, de los cuales 47 convenios oscilaron entre mil y cinco mil millones de pesos; 10 convenios entre cinco mil y veinte mil millones, y alrededor de seis convenios superaron los veinte mil millones de pesos con un tope de cuarenta y cuatro mil millones de pesos $\mathrm{m} / \mathrm{cte}$, los demás estuvieron por debajo de los mil millones de pesos $\mathrm{m} / \mathrm{cte}$. 
De lo anterior, vale la pena resaltar algunos convenios que al parecer no conllevan un verdadero aporte internacional que propenda por el desarrollo del País en materia de Educación, como es el caso de convenios de Cooperación Internacional que desde el año 2010 convenios de ha suscrito anualmente el MEN con la Organización de Estados Iberoamericanos -OEI cuyo objeto corresponde a "aunar esfuerzos de carácter técnico, logístico, administrativo, financiero y operativo para el desarrollo de las actividades del sistema de aseguramiento de la calidad, la inspección y vigilancia de la Educación Superior" (Colombia Compra Eficiente, 2015).

$\mathrm{Al}$ analizar los convenios mencionados anteriormente se puede observar que, a través de su objeto se llevan a cabo funciones propias de la entidad, situación que esprohibida per la ley,toda vez que conforme a la estructura organizacional y funciones del MEN, estas funciones recaen sobre las "Subdirecciones de Aseguramiento de la Calidad y de la Inspección y Vigilancia de la Educación Superior", por lo que al desarrollarse por el Organismo Internacional este necesariamente subcontrata personal para el desarrollo de las mismas, situación que podría desencadenar en la configuración de las polémicas llamadas "nóminas paralelas", de las cuales nos referiremos más adelante.

A su vez, como antecedente de esta contratación, en años anteriores al 2010, el desarrollo de este objeto lo realizó la entidad “Alma Mater”, que es la Red de Universidades Públicas del eje cafetero, a través de un contrato interadministrativo, lo que nos lleva a concluir que el objeto no necesariamente necesita ser desarrollado por un Organismo Internacional, ni mucho menos a través de un convenio de cooperación internacional.

Así mismo, en el año 2012 se celebraron convenios con la Organización de Estados Iberoamericanos -OEI y la Organización Internacional para las Migraciones -OIM cuyo objeto era atender la emergencia de Ola Invernal “Fenómeno del niño 2010-2011”, reconstrucción de escuelas, mobiliario y útiles escolares, por valores de \$30 y 28 mil millones respectivamente, donde el objeto principal se componía de 3 fases en particular: (i) visitas de diagnóstico y ayuda humanitaria, (ii) reparaciones locativas estructurales y obras de mitigación y (iii) reconstrucción o 
reubicación, por valores de treinta mil millones y veintiocho mil millones de pesos, respectivamente.

Una vez analizados estos convenios con la OEI y OIM, vemos que las actividades desarrolladas comprendieron obras de infraestructura e ingeniería y dotación de útiles escolares, actividades que resultaron siendo ejecutadas por subcontratistas nacionales contratados por medio de las organizaciones internacionales, situación que demuestra que estas organizaciones terminaron siendo meros intermediarios y recibiendo un porcentaje por comisión, lo que puede denotar que resultaron“ administrando recursos púbicos” figura expresamente prohibida por la Ley. En este orden de ideas, es evidente la ausencia del componente o aporte internacional.

Para ilustrar lo anterior, dentro de los convenios suscritos para atender la emergencia de la "Ola invernal" además de los organismos ya mencionados como la OEI y OIM, hubo uno suscrito con el Fondo Financiero de Proyectos de Desarrollo (FONADE), todos para desarrollar el mismo objeto. Es preciso indicar que FONADE no es un organismo internacional.

Por su parte. en este punto es pertinente plantear un par de interrogantes. Primero, ¿será que estas contrataciones realizadas a través de modalidad directa constituyen una forma de evadir los procesos de selección establecidos por en el Estatuto de Contratación Estatal? En segundo lugar, ¿Será que estos objetos requirieron de un Organismo Internacional para ser desarrollados?

Frente a los anteriores interrogantes planteados y a raíz de todo lo expuesto, es posible afirmar que la contratación con Organismos Internacionales de Cooperación que se hace de manera directa y sin la rigurosidad que exige el Estatuto de Contratación es una forma de evadir los procesos de selección previstos en el mencionado estatuto. Por otro lado, frente al segundo interrogante y del análisis de algunos convenios suscritos por el MEN, vemos que algunos de los objetos de los mismos, no requerían para su ejecución de un Organismo Internacional.

Ahora bien, como complemento de lo mencionado, se relacionan en documento anexo los convenios suscritos durante los últimos diez años en el MEN, en los cuales, si bien se ven objetos relacionados con la Educación, al entrar a analizar cada uno de ellos se logró determinar que en 
algunos los objetos no fueron desarrollados por el Organismo Internacional, pues este término subcontratando la ejecución del mismo a un contratista nacional. (www.colombiaeficiente.gov.co)

No obstante lo anterior, es válido aclarar que el Ministerio de Educación Nacional ha suscrito varios convenios que en realidad versan sobre un objetivo claro y conllevan un verdadero aporte internacional. Como por ejemplo, algunos de muchos convenios, es el suscrito con la UNICEF para el año 2009, cuyo objeto consistió en:

"Realizar acciones conjuntas para aunar esfuerzos con el fin de desarrollar procesos de fortalecimiento institucional e interinstitucional a través de la cualificación, implementación y expansión de los programas aulas en paz y pedagogía y protección de la niñez, como programas estructurados que desarrollan competencias ciudadanas en contextos de violencia en los ámbitos nacional, regional y local" (Convenio UNICEF, 2009).

Otro de los convenios donde se puede apreciar aporte internacional fue el suscrito con la OECD en el año 2011, con el propósito de:

“La OCDE llevará a cabo las actividades previstas en el Programa de Trabajo y Presupuesto para 2011-2012 con el fin de garantizar la participación de Colombia en la fase 2 del área de competencias genéricas del estudio de factibilidad AHELO (Evaluación de los Resultados de la Educación Superior) con el fin de desarrollar una prueba que permita medir la calidad de la educación superior en términos de resultados del aprendizaje y evaluar la comparabilidad de los datos con otros países".

En los dos últimos convenios mencionados, se puede apreciar que existieron verdaderos aportes internacionales en pro de la educación como base del desarrollo social del País.

Ahora bien, los convenios citados son algunos ejemplos, sin embargo para darnos un idea más amplia de lo que ha sido la contratación con organismos internacionales durante los últimos 
diez años en el Ministerio de Educación Nacional, en el documento anexo mencionado se relacionan los mismos indicando objeto, valor, y año de su celebración.

\section{ANÁLISIS COMPARADO DE LA CONTRATACIÓN CON ORGANISMOS INTERNACIONALES: EL CASO DE URUGUAY}

Ahora, entraremos a realizar un análisis sobre la regulación y aplicación de las leyes contractuales en URUGUAY en materia de celebración de convenios con Organismos de Cooperación Internacional, no sin antes mencionar de manera global cómo se desarrolla en general la actividad contractual en este país

Así las cosas, vemos que URUGUAY, en materia de contratación, no cuenta con una normatividad sistemática y organizada. Por el contrario, "existe un conjunto de disposiciones que regulan el procedimiento administrativo de la licitación pública y múltiples normas dispersas referentes a distintos aspectos de los diversos contratos posibles" (Delpiazzo, 2013). Ello permite que en materia de contratación estatal existan otras normas que garanticen el cumplimiento de los contratos y la buena administración de los recursos del Estado.

Por otro lado, se le da gran importancia al principio de concurrencia, el cual postula la participación en la comparación de ofertas de la licitación de la mayor cantidad posible de oferentes, de modo tal que la autoridad cuente con la más amplia gama de alternativas de elección, para escoger con más posibilidad de acierto la que proponga las mejores condiciones según el objeto específico de cada licitación (Delpiazzo, 2013, pág. 7).

En este sentido, se puede indicar que, al no estar regulada la contratación estatal por un ordenamiento legal unificado, es posible que otras áreas del derecho interfieran en la celebración del contrato, tomando otras fuentes secundarias del derecho para reglamentar la actividad contractual de Uruguay; por ejemplo, a través de los principios generales del derecho, los cuales permiten que haya competencia, trasparencia y veracidad entre los oferentes a fin de obtener beneficios de todo tipo para el Estado. 
Ahora bien, de manera general en cuanto a los procedimientos de contratación, se encuentra la licitación abreviada, la cual consiste en un procedimiento que se limita a establecer determinadas características, por ejemplo, el número mínimo de invitados. Por otro lado, está la licitación privada, que procede "cuando la licitación pública, abreviada o remate resultaren desiertos, o no se presentaren ofertas válidas o admisibles, o las mismas sean manifiestamente inconvenientes" (Ley TOCAF, artículo 33).

En tercer lugar, se ubica la contratación directa, en la cual la entidad estatal elige discrecionalmente a la otra parte para celebrar el contrato. No obstante, "la discrecionalidad no debe confundirse con el sistema de libre elección en la formación del contrato, ya que la contratación directa está regulada y prefigurada como un mecanismo excepcional" (Delpiazzo, 2013), pues sólo se da en las situaciones que prevé la Ley para tal fin.

Por último, concurren los procedimientos especiales dentro de los cuales se desarrolla la contratación para la adquisición de bienes y servicios con organismos internacionales. Esta modalidad contractual, se desarrolla a través de la Agencia Uruguaya para la Cooperación Internacional, la cual se creó en el año 2010 como órgano desconcentrado y con autonomía propia, con el ánimo de planificar, diseñar, supervisar, administrar, coordinar, ejecutar, evaluar las actividades proyectos y programas de cooperación internacional para dar cumplimiento a las políticas de desarrollo del país. Los proyectos se efectúan a través de acuerdos de cooperación internacional con los organismos internacionales a los que está adherida la Nación. (Verocai, 2015).

Así las cosas, después de una comparación entre la legislación de Uruguay y la de Colombia, se puede afirmar que ambas legislaciones cuentan con procedimientos especiales cuando se contrata con organismos internacionales y ambas naciones cuentan con una agencia especializada para la cooperación internacional; no obstante, en Uruguay esta agencia se encarga de promover y ejecutar la cooperación internacional a través de proyectos formulados por medio de acuerdos y contrataciones de carácter internacional. 


\section{POSIBLES EFECTOS EN LA CELEBRACIÓN DE CONVENIOS DE COOPERACIÓN INTERNACIONAL}

A continuación se dará a conocer algunos de los principales efectos que podrían presentarse ante prácticas inadecuadas en la celebración de convenios de cooperación.

En primer lugar, en relación a la ausencia de componente internacional, es posible mencionar que se trata de un contrato sin el lleno de requisitos plenos, dado que para que nazca o se celebre un convenio de cooperación internacional, el mismo debe contemplar el componente internacional que propenda por el desarrollo social del país. Al respecto, mediante la Circular conjunta número 014 de 2011 expedida por la Contraloría General de la Republica, la Auditoría General de la Republica y la Procuraduría General de la Nación se indicó que el principal objetivo de cualquier contratación estatal es cumplir con el fin específico que la motiva, la cual debe buscar la satisfacción de la necesidad de la entidad que solo se verá garantizada si se delimita bien el objeto, las obligaciones o compromisos y demás aspectos fundamentales que llevaron a la contratación directa. (Contraloría General de la Republica y Auditoria General de la Republica, 2011).

En cuanto al concepto de celebración de contrato sin el lleno de requisitos plenos, la Corte Constitucional expresa que aunque la Ley 80 de 1993 no hace referencia expresa a los requisitos esenciales del contrato administrativo, la Ley remite a las disposiciones comerciales y civiles pertinentes, en el artículo 13 de la Ley. El Código Civil distingue en cada contrato lo que es de su esencia, de su naturaleza y lo accidental. Por ello, la inobservancia de los requisitos legales esenciales puede estar referida a la validez, a la existencia, a la eficacia o a la ejecución de los contrato (Sentencia C-917 de 2001).

Lo anterior debe tenerse en cuenta, no sólo por el cumplimiento de los requisitos legales en materia contractual, sino también porque acarrearía responsabilidad derivada de la actuación administrativa, de conformidad con lo establecido los artículos 6, 123-2, 124 de la Constitución y el artículo 51 de la Ley 80 de 1993, en donde se establece que en materia contractual, los servidores públicos responderán disciplinaria, civil y penalmente por sus actuaciones. 
Ante la inaplicación y evasión de los procesos de selección establecidos en el Estatuto de Contratación Estatal por parte de la Administración para acudir a la celebración de convenios de cooperación internacional, puede configurarse un "desvío de poder"; es decir, una conducta irregular de la administración que conduce a un fin pero con un procedimiento equivocado, generalmente, con el propósito de favorecer sus propios intereses (Lamprea, 1996). Al respecto, el desvío de poder no es más que una de las causas que llevan a la configuración del delito de indebida celebración de contratos. Por esta razón, cuando el legislador estructuró el delito de interés indebido en la celebración de contratos, lo que hizo fue elevar a la categoría de delito el desvío de poder dentro de la contratación estatal, que podría conllevar a que el acto fuera nulo, porque la Administración prescindió del procedimiento exigido por la ley (Santamaria Pastor, 1975).

Según la jurisprudencia y la doctrina clasifican las diferentes manifestaciones de la desviación de poder, generalmente en dos grandes grupos: aquellos casos en que (1) el acto o contrato administrativo es ajeno a cualquier interés público -venganza personal, motivación política, interés de un tercero o del propio funcionario-, (2) el acto o contrato es adoptado en desarrollo de un interés público, pero que no es aquel para el cual le fue conferida competencia a quien lo expide o celebra; categoría a la que se aproxima igualmente la desviación de procedimiento en la que la administración disimula el contenido real de un acto, bajo una falsa apariencia, recurriendo a un procedimiento reservado por la ley a otros fines, con el fin de eludir ciertas formalidades o de suprimir ciertas garantías. (Sentencia 0752-09, 2011)

Por otra parte, uno de los mayores desaciertos en que incurre la Administración es la celebración de Convenios de Cooperación con objetos poco pertinentes y conducentes, excesivamente onerosos y con ausencia de aporte internacional. Esto denota que son resultado de una falta de planeación, pues son utilizados con el fin de agotar el presupuesto anual asignado en la respectiva vigencia y de este modo evitar sanciones por la no ejecución de los mismos y cumplir con el principio de anualidad. Esta situación puede desencadenar en una eventual celebración de contratos contrarios al interés público, pues los contratos deben ser pertinentes, 
deben ser conducentes, debe haber una buena inversión del gasto público, deben redundar en beneficio para la comunidad, deben reflejar resultados o por lo menos servir de medio para el logro de resultados (Roseeau, 1990).

En efecto, el hecho de que las entidades estatales deban celebrar sus contratos conforme a los postulados del Estatuto de Contratación estatal, al ordenamiento jurídico y a los principios de la buena administración implica que si la administración celebra contratos con objetos no pertinentes, que no representan una buena inversión del gasto público, ni representan intereses para la comunidad y no reflejan resultados, esta celebrado contratos contrarios al interés público y por ende, contrarios a la ley. Esta práctica desencadena en una ilegalidad de los mismos, ya que las entidades estatales tienen el deber de verificar y supervisar la correcta ejecución del objeto y el cumplimiento de las obligaciones contractuales pactadas, y en caso de no darse esta situación, se estaría presentando una posible desnaturalización de la modalidad contractual prevista.

De igual forma, podemos decir que estamos ante la inaplicación de las leyes contractuales por interpretación errónea del artículo 20 de la Ley 1150 de 2007, pues se aplica la modalidad de contratación de manera directa cuando se celebren convenios de cooperación internacional, aun cuando no existe el componente internacional.

Aunado a lo anterior, resulta válido plantear una posible nulidad absoluta de contrato. Es decir, que si con la suscripción de convenios con organismos de cooperación internacional no es evidente el componente internacional, esto es un aporte o beneficio en pro del desarrollo del país, puede presentarse una posible nulidad del contrato. El fundamento de ello es el artículo 1502 del código civil, según el cual, para que un contrato sea válido debe reunir, entre otros los siguientes requisitos: (i) que el objeto del contrato sea lícito, es decir, que el fin perseguido sea permitido por las normas y (ii) una causa lícita, que consiste en el motivo que impulsa a las partes a suscribir un contrato. Entonces, si un contrato no cumple estos requisitos, está viciado de nulidad la cual puede ser relativa o absoluta. En ese orden de ideas, se observa que la falta de componente internacional dentro del objeto del convenio internacional obedece a una causa ilícita, ya que desvirtúa la posibilidad de encontrarse frente a esta modalidad contractual por cuanto no cumple con su objetivo principal que es el componente y/o aporte internacional. 
Según la Teoría de Domat, la ausencia o falta de causa y la falsa causa dan lugar o bien a la existencia o bien a la nulidad absoluta del contrato respectivo acuerdo a las reglas generales de las nulidades absoluta o relativa de los actos o negocios jurídicos. Estas no solo ponen fin a la eficacia futura del acto, sino que también debe obrar retroactivamente destruyendo los posibles efectos que haya alcanzado (Dominguez Aguila, 1977)

En relación a la Nulidad Absoluta el Consejo de Estado ha dicho lo siguiente:

"De modo que no toda irregularidad o violación a la ley o a la Constitución, configura la celebración de un contrato “... contra expresa prohibición constitucional o legal.” Es necesario analizar, en cada caso concreto, el contenido de la norma, para determinar si contempla una prohibición a la celebración de un contrato o si contiene simplemente otro tipo de requisitos, cuya trasgresión o pretermisión pudiera generar la nulidad absoluta del contrato o una consecuencia diferente”. (Sentencia 02505-0, 2007)

Ahora bien, si se está frente a una falsa causa, se hablaría de una nulidad relativa. Según el artículo 1524 del código civil colombiano, para que los móviles falsos o erróneos lleguen a ser sancionados, deben concurrir dos condiciones: (i) que estos móviles sean determinantes, es decir, que induzcan a la celebración del acto jurídico o contrato; (ii) que se trate de móviles comunes, conocidos por las partes.

En síntesis y a modo de conclusión, puede afirmarse que la celebración de convenios con organismos internacionales conlleva a distintas consecuencias, las cuales pueden ser positivas o negativas para el país y/o ente que las celebra. Este resultado depende de cómo se efectúen, pues si cumple con los requisitos de fondo y se obtiene un aporte de carácter internacional que ayude al desarrollo del país, se está ante un resultado positivo, por ejemplo, es el caso de algunos convenios citados en los cuales se observa plenamente el gran aporte internacional en pro del desarrollo del país. 


\section{CRÍTICAS A LA CONTRATACIÓN ESTATAL CON ÓRgANOS INTERNACIONALES}

Una de las más duras críticas en la contratación con Organismos internacionales es el régimen especial aplicable para esta clase de convenios, en los que de alguna forma se imposibilita al Estado Colombiano a coaccionar a las Organizaciones Internacionales ante un eventual incumplimiento de los compromisos adquiridos en el marco de los convenios suscritos, dado que estos se rigen por sus reglamentos, los cuales no contemplan garantías que puedan amparar la correcta ejecución del convenio y los posibles perjuicios que lleguen a resultar, además de que imposibilita a las entidades estatales a establecer las cláusulas exorbitantes propias del contrato estatal. En este punto ser observa un gran vacío normativo en cuanto a la jurisdicción competente para conocer de los conflictos que pudieran surgir ante un incumplimiento de los compromisos adquiridos en los convenios de cooperación internacional, vacío que nace de la inmunidad de ejecución y jurisdicción que ostentan las Organizaciones Internacionales (Ramos Venegas, 2009).

Sobre la base de lo anterior, se puede decir que la inmunidad, de manera general, debe entenderse como "aquel conjunto de privilegios, prerrogativas y exenciones del cual gozan algunos órganos de derecho internacional, bien sea personales o en conjunto. Por consiguiente, las inmunidades de los órganos nacionales se denominan inmunidades o privilegios diplomáticos $\mathrm{y}$, por su parte, la inmunidad de la cual gozan los agentes, funcionarios internacionales o los órganos internacionales se denomina inmunidad internacional o derecho de inmunidad internacional, el cual está regentado por el derecho internacional organizacional" (Sentencia $3446,2009)$.

En ese orden de ideas, el gobierno colombiano, cuando reconoce la personería jurídica de los Organismos Internacionales, concede inmunidades y privilegios diplomáticos a sus integrantes y a la organización misma mediante ley ordinaria, dentro de las que encontramos la "inmunidad diplomática" a funcionarios de nacionalidad distinta a la colombiana y la inmunidad de jurisdicción sobre los bienes que integran su patrimonio, inviolabilidad de archivos y documentos. Estas prerrogativas pueden constituir un riesgo y por ende, una real debilidad si son 
invocadas por el organismo para evadir la responsabilidad derivada de la relación contractual o incluso para entorpecer el ejercicio de los controles que recaen sobre la entidad pública (Mutis, 2000).

Igualmente, a través de estos convenios de cooperación internacional, resulta común afirmar que en la actualidad, se ha implantado como práctica usual en las relaciones laborales con el Estado la reducción de las plantas de personal de las entidades públicas, el aumento de contratos de prestación de servicios para el desempeño de funciones permanentes de la Administración, lo que públicamente se conoce como "nóminas paralelas" o designación de una gran cantidad de personas que trabaja de forma directa para ciertas entidades públicas a través de outsoursing. (Villegas Arbeláez, 2011)

Ante estas problemáticas, el Contralor General de la Republica, Dr Hernández Gamarra, en un informe de control fiscal de 2008,sugirió que las diferentes entidades gubernamentales realicen un análisis minucioso de la conveniencia o necesidad de la suscripción de cada uno de los convenios de cooperación internacional. Además, se mostró partidario de desarrollar y estandarizar indicadores de gestión e impacto, que permitan medir los resultados obtenidos con el establecimiento de los convenios de cooperación.

Aunado a lo anterior, se observan otras prácticas utilizadas en la celebración de los convenios de cooperación internacional, lo cual ha desconfigurado la naturaleza por la cual fueron creados los organismos de cooperación en marco del derecho internacional, tales como: (i) algunos convenios no comprenden un aporte internacional que propenda por el desarrollo del país; (ii) en otros convenios, el aporte internacional tal como lo exige la norma ( art 20 ley 1150 de 2007) no es el que se esperaría, toda vez que las contrapartidas son representadas en especie que muchas veces carecen de objetividad y resultan siendo de papel; (iii) a través de estos convenios continua la práctica de "administración de recursos", la cual actualmente es prohibida por la ley; (iv) se desnaturaliza la cooperación que debería ser el fin último del convenio, siendo en realidad una prestación de servicios, donde la entidad estatal termina pagando al Organismo para que este desarrolle un proyecto a través de un subcontratista nacional contratado por el mismo organismo internacional, sin que se vislumbre una verdadera cooperación internacional; 
(vi) estas contrataciones, al carecer de estimación de riesgos y garantías contractuales impiden a las entidades acudir a un resarcimiento de perjuicios en un eventual incumplimiento de los compromisos adquiridos por el " cooperante", quien, además, resulta amparado por la inmunidad diplomática.

De otra parte, es preciso indicar que, generalmente, los aportes dentro del convenio son representados en dinero y en especie. El dinero lo aporta la entidad pública y el organismo hace su aporte en especie, el cual por prescripción del estatuto de contratación debe ser cuantificado en dinero. Sin embargo en algunos casos, el aporte en especie, a veces, no compensa la magnitud del objeto desarrollado frente a los recursos allí destinados por la entidad en el marco del convenio que se suscribe.

\section{CONCLUSIONES}

Primera: El sistema de contratación del Ministerio de Educación Nacional representa un valor significativo en su presupuesto asignado durante la última década, frente a un número menor de convenios de cooperación suscritos en este lapso, de los cuales en algunos se han conseguido importantes aportes internacionales para la Educación del país, y en otros casos se han ejecutado convenios donde el principal ausente resulta ser la Cooperación Internacional..

Segunda: Con la celebración de convenios con organismos internacionales se han presentado situaciones que irían en contra de los principios de la contratación estatal, pues debido a una mala planeación se termina acudiendo a la celebración de convenios de cooperación internacional, donde el principal ausente es el aporte internacional, además de ser una forma de evadir los procesos de selección de contratistas que prevé el Estatuto de contratación estatal.

Tercera: Los efectos de este tipo de convenios, cuando no son utilizados correctamente, pueden desencadenar en situaciones que irían en contra de la ley, pues con ellos se estarían estableciendo nóminas paralelas. Además, de que algunos resultan siendo muy onerosos para el resultado que se logra, especialmente, cuando no existe un verdadero y tangible aporte internacional. 
Cuarta: La celebración de algunos de estos convenios de cooperación internacional, que no logran el objetivo de la norma, conduce a establecer hipótesis como la configuración de un desvío de poder, es decir, celebración de contratos sin el lleno de requisitos plenos y, por ende, la posible nulidad absoluta del convenio celebrado. Asimismo, la imposibilidad de contar con mecanismos ante un eventual incumplimiento de los compromisos adquiridos en marco de estos convenios, en razón de la inmunidad diplomática de la cual gozan estos entes y sus respetivos representantes legales.

\section{Quinta: Comparada la contratación con Organismos Internacionales de nuestro país}

con Uruguay, vemos que allí se cuenta con una Oficina especializada para proyectos internacionales, encargada de la preparación, la supervisión y ejecución de convenios celebrados, lo que permite que esta modalidad contractual se efectué de manera positiva y efectiva que representa aportes internacionales en materia de cooperación con organismos internacionales.

Sexta: Una posible solución a esta problemática en la mala práctica en la celebración de convenios de cooperación, puede ser que, los convenios de cooperación internacional que celebren la entidades estatales, entre ellas el Ministerio de Educación Nacional sean previamente avalados por la Agencia Presidencial de Cooperación Internacional de Colombia APC como entidad creada para gestionar, orientar y coordinar la cooperación internacional pública, es por esta razón sería viable optar por una reforma al artículo 20 de la Ley 1150 de 2007 frente a la obligación de las entidades estatales de presentar previamente sus proyectos para su aprobación ante la APC, con el fin de que a través de esta agencia se evalué y se apruebe el aporte internacional en marco de los convenios que se pretenden suscribir.

Séptima: Teniendo en cuenta la cantidad de proyectos que en materia de Cooperación Internacional suscribe el país día a día, se propone fortalecer la Agencia Presidencial de Cooperación Internacional de Colombia APC. Lo anterior, dado a que tal como está estructurada resulta ser insuficiente para cubrir la cantidad de proyectos que demanda la cooperación internacional que se pretende. Con una Agencia más fortalecida se alcanzarían mayores logros y beneficios en pro del desarrollo del país a través la figura de cooperación internacional. 


\section{REFERENCIAS}

Alessandri Rodriguez, a. (2000). De los contratos. Chile: Editorial Juridica de Chile.

Alvarado, K. (Agosto de 2007). Gestion publica. Recuperado el 22 de Abril de 2015, de Contrataciones y Adquisiciones del Estado - El Sistema de Contratación Estatal: http://www.gestionpublica.org.pe/plantilla/practx09/contrat_estado/2007/compest_07_1.p df

Alvarez, R., Giancolome, R., \& Sandoval, J. M. (1998). Globalización, integración y fronteras en America Latina. Merida, Venezuela: Universidad de la Andes.

Aristizabal, L. A. (2007). La cooperacion internacional y su regimen juridico en Colombia. Bogotá: Area de gestión de comunicaciones-Accion Social.

Argentina, Ministerio de Economía y Finanzas Públicas. 2001. InfoLEG. Recuperado de Centro de Documentación e Información: http://infoleg. Ministerio de Educacion Nacional. (s.f.). Recuperado el 06 de Junio de 2015, de http://www.mineducacion.gov.co/1621/w3arxticle-85243.html

Acción Social. Presidencia de la Republica a. (2011). Guia de contratación estatal, convenios de cooperación internacional. Bogotá:Imprenta Nacional.

Barberis, j. a. (1982). El concepto de tratado internacional. España: Anuario de derecho internacional.

Barbosa, B. (2005). Contratos Estatales. Bogotá D.C. Ediciones Jurídicas Gustavo Ibañez Ltda.

Barra, R. (2011). Aspectos jurídicos del presupuesto. Argentina. La Ley

Benavides, J. L. (2004). El contrato estatal. Entre el derecho público y el derecho privado. Bogota D.C.: Universidad Externado de Colombia.

Benavides, J. L \& Santofimio J.O (2009). Estudios sobre la reforma del estatuto contractual. Bogota: Universidad Externado de Colombia.

Bueno de Mesquita, B. B. (2006). Principles of Internationals Politics. Washington: CQ Press. Cassagne, J. C. (1981). El contrato adminstrativo. Buenos Aires: Editorial Lexisnexis.

Castro Cuenca, C. G; Garcia Lopez, L. F; Martinez Vargas, J R. (2010). La contratación Estatal: teoria general -prespectiva comparada y regulacion internacional. Bogotá: Universidad del Rosario. 
Chavez, M. (2008). Los convenios de la administracion:ente la gestion publica y la actividad negocial. Bogota: Universidad del Rosario- pag 235 y ss.

Diaz Briones, K.(2010). Convenios Internacionales. Documento del Banco Interamericano de Desarrollo.

Colombia Compra Eficiente. (02 de Mayo de 2015). Sistema electrónico de contratación pública. Recuperado de http://www.colombiacompra.gov.co/es/secop

Colombia Compra Eficiente. (s.f.). Colombia Compra Eficiente. Recuperado de Colombia CompraEficiente:

http://colombiacompra.gov.co/sites/default/files/manuales/manualpaa.pdf

Colombia, (Secretaría General Alcaldía Mayor de Bogotá D.C. Concepto 72 de 2008 del 06 de Junio de 2008).

Colombia, Procuraduría primera delegada ante el Consejo de Estado.Concepto No. 298 /2012, Expediente: 42.282 (2011-00065).

Colombia, Agencia de la Presidencia para la Cooperación Internacional (2008). La cooperación internacional y sus regimen jurídico en Colombia. Bogotá: Imprenta Nacional.

Colombia, Sentencia, Expediente 18.403 (Consejo de Estado, Sala de lo Contencioso Administrativo, Sección Tercera. 10 de Febrero de 2010).

Colombia, Sentencia C 15324, 15324 (Corte Constitucional 29 de Agosto de 2007).

Colombia, Sentencia, 12344 (Consejo de Estado. Consejero Daniel Suarez Hernandez 1999).

Colombia, Sentencia, D 4869 (Corte Constitucional Mag Jaime Araujo Renteneria 16 de marzo de 2004).

Colombia, Sentencia, C- 027 (Corte Constitucional / MP Jorge Ignacio Pretel 26 de enero de 2011).

Colombia, Sentencia C 192, 192 (Corte Constitucional / MP Alejandro Martinez Ordoñez 15 de abril de 1997).

Colombia, Sentencia 3446 (Consejo de Estado. MP Miriam Guerrero de Escobar 26 de Marzo de 2009).

Colombia, Sentencia 02505-1. Consejo de Estado. Sala de lo contencioso administrativo. Sección tercera. M.P. Alier Eduardo Hernández Enríquez. Bogotá d.c., marzo veintidós (22) de dos mil siete (2007)

Colombia, Sentencia 16209 (Consejo de Estado/ MP Ramiro Saavedra Becerra 3 de mayo de 2007 
Colombia, Sentencia C 614 (Corte Constitucional / MP Jorge Ignacio Pretel 2 de Septiembre de 2009).

Colombia, Sentencia C-040/00, Expediente D-2457 (Corte Constitucional. M.P. Dr. Fabio Moron Diaz 26 de Enero de 2000).

Colombia, sentencia 0752-09, Consejo de Estado. Sala de lo contencioso administrativo. Seccion segunda. M.P. Gustavo Eduardo Gómez Aranguren .29 de junio de 2011.

Colombia, Sentencia C-189 de 1998 , Expediente D-1859 (Corte Constitucional 06 de Mayo de 1998).

Colombia, Sentencia C-508 de 2002, Expedientes D-3871 (Corte Constitucional. M.P. Alfredo Beltrán Sierra 3 de Julio de 2002).

Colombia, Sentencia C-917 de 2001, Sentencia C-917 de 2001 (Corte Constitucional Colombiana 29 de Agosto de 2011).

Colombia Ministerio de Hacienda y Crédito Público Conceptos Jurídicos Presupuestales. Echeverry Garzón , J. (2011).. Bogotá: kimpres ltda.

Colombia, Sentencia C 614 (Corte Constitucional / MP Jorge Ignacio Pretel 2 de Septiembre de 2009).

Colombia, Sentencia C 192 (Corte Constitucional/MP Alejandro Martinez Caballero 15 de abril de 1997).

Colombia, Sentencia 15324 (Consejo de Estado, Sección tercera. Sala de lo Contencioso Administrativo. MP Mauricio Fajardo 29 de Agosto de 2007).

Colombia, Sentencia 12932 (Consejo de Estado, Sala de lo Contecioso Administrativo, Seccion Tercera. Consejero Ponente: Dr. Ramiro Saavedra Becerra 20 de Mayo de 2004).

Colombia, Sentencia 16432 (Consejo de Estado. Sala de lo Contencioso Administrativo.

Seccion Tercera. M.P Mauricio Fajardo Gómez. Bogotá d.c., 14 de abril de 2010.

Colombia. Fallo 214-158579/07 (Procuraduria General de la Nación 24 de Abril de 2007).

Colombia. Acción Social. Presidencia de la Republica A. (2007). La cooperacion internacional y el derecho. Bogotá: Area de gestion de comunicaciones.

Colombia, Acción Social. Presidencia de la Republica (2008). La cooperación internacional y su régimen jurídico en colombia. Bogotá: Imprenta Nacional. 
Colombia. Contraloria y Auditoria Generales de la Republica y Procuraduria General de la Nación. Circular Conjunta 014 de 2011. Contratación Directa-leyes 80 de 1993 y 1150 de 2007, causales de urgencia manifiesta y contratos interadministrativos. Bogotá.

Colombia,Manual de formulación de proyectos de cooperación internacional. recuperado el 7 de junio de 2015 de (http://www.apccolombia.gov.co/recursos_user//Documentos/ManualFormulacion-Proyectos.pdf)

Colombia. Ministerio de Educación Nacional recuperado el 13 de julio de 2015 (http://www.mineducacion.gov.co/1621/w3-channel.html)

Colombia, Contraloría General de la Republica. Informe de Control Fiscal 2008. Contralor General de la República, Dr Hernández Gamarra, 2008,

Corredor, L. A. (2009). Oportunidades de Financiamiento Para los entes locales en el Siglo XXI. España: Eumed.

Convenio Andrés Bello - CAB, recuperado el 189 de julio de 2015 http://convenioandresbello.org/inicio/blog/2014/08/14/un-primer-vistazo-a-los-objetivos-dedesarrollo-sostenible/.

Cuenca, C. C., \& López, L. F. (2010). Los principios de la función y de la contratación pública. En C. C. Cuenca, L. F. López, \& J. R. Vargas, La contratación estatal. Teoría general. Perspectiva comparada y regulación internacional. Bogota D.C. Universidad del Rosario.

Del Piazzo, C. (2006). Los Principios Generales en la Contratación Pública . Buenos Aires.

Delpiazzo, C. E. (2013). Panorama de la Contratación Pública en Uruguay. Revista de Derecho Administrativo Bogota : Universidad Externado de Colombia.

Diez de Velasco, M. (1997). las organizaciones internacionales. Madrid: Tecnos.

Dominguez Aguilar, R. (1977). Teoria General del Negocio Jurídico. Chile: Jurídica de Chile.

Dromi, J. R. (1977). Licitacion publica. Buenos Aires: Astrea.

Estrada Sánchez, J. P. (2009). Contratación directa, contratos interadminitrativos y contratos de cooperación internacional. En J. O. Jose Luis Benavides, Contratación Estatal (pág. 129). Bogotá: Universidad Externado de Colombia.

Exposito, Velez, (2008). La configuracion del contrato de la administracion publica en derecho. bogota: universidad externado de colombia.

Fandiño Gallo, J. (2009). Regimen Juridico del Contrato Estatal. Bogotá: Leyer. 
Figueroa Pla, U. (1991). Organismos Internacionales. Santiago de Chile: Editorial Juridica de Chile.

Gamboa, J. O. (2004). Tratado de Derecho Administrativo. Bogota D.C.: Universidad Externado de Colombia.

Gámes Viscaino, J. M. (2002). Manual de procedimiento de la contratacion estatal. Bogotá: Legis Editores SA.

Gastón, P. G. (2009). Nuevo contexto de la Cooperacion Internacional. OEA.lsegib Gutierrez Espada, C. (1995). Derecho internacional público. Madrid, España: Trotta.

Gómez Lee, D. (2012). El derecho de la contratación pública en Colombia. Bogotá: legis.

Herrera Robles, A. (2012). Aspectos generales del derecho administrativo colombiano (3a ed.). Universidad del Norte.

Herrera, B. B, Riveros. S H, \& León N. L (1996). Régimen de contratación estatal. Bogotá D.C.: Universidad Externado de Colombia.

Herrera, Barbosa. B. (1996). Regimen de contratacion estatal, principio de la contratacion estatal. bogota: Universidad Externado de Colombia.

Hincapié, J. (2008). La transparencia de la contratación del Estado. Bogotá: Doctrina y Ley. http://tcdc2.undp.org/GSSDacademy/video/pdf/Columbia\%20Javier\%20_j\%28spanish\%2 9.pdf. (s.f.).

Lamprea, P. A. (1996). Anulacion de los actos de administración pública. Bogota: Doctina y ley. Maldonado Bodart, M. (2013). Los organismos internacionales en la era global: los nuevos retos de la cooperación internacional. México: Editorial Miguel Ángel Porrúa.

Marienhoff, M. (1990). Tratado de derecho adminitrativo t.iii. Buenos Aires: Abeledo Perrot pag 154.

Matallana Camacho, E. (2004). Contratacion con Organismos de Cooperacion Internacional. Revista Derecho del Estado No. 16, 85-98.

Melo, B. C. (2012). Contratación estatal. Manual teórico-práctico. Medellin: Ediciones de la U.

Merle, M. (1985). Le rôle du facteur culturel dans les relations internationales/El papel del factor cultural en las relaciones internacionales. París: Economica, pág. 339.

Ministerio de Educación Nacional. (03 de Abril de 2015). Ministerio de Educación Nacional. Obtenido de MINEDUCACION: http://www.mineducacion.gov.co/1621/w3-article85252.html 
Ministerio de Hacienda y Credito Público. (2011). Aspectos Generales del Proceso Presupuestal Colombiano. Bogotá: Kimpres Ltda.

Ministerio de Hacienda y Crédito Público. (2011). El Presupuesto Público: Definición y Conceptos Básicos. En Aspectos generales del proceso presupuestal colombiano. Bogotá D.C. : Biblioteca "José María Del Castillo y Rada".

Ministerio de Relaciones Exteriores, C. (2013). Relativo a la naturaleza jurídica y relación entre los Acuerdos o Tratados Internacionales marco y los Convenios Interinstitucionales. Bogotá: Casa Editorial Ltda.

Monroy Cabra, M. (2011). Derecho Internacional Público. Bogotá: Temis 6a edición.

Morales Restrepo, D. (2012). Régimen de la contratacion estatal anotado. Bogotá: Leyer.

Morelli, S., Gómez Lee. I., Ordoñez, A.,(2011). Circular Conjunta No. 14. Contratación Directaley 80 de 1993.

Mutis Vargas, A., \& Quintero Munera, A. (2000). La contratacion estatal análisis y perspectivas. Bogotá 1a Ed: JavieGraf.

Naranjo Flórez, C., \& Cely Cubides, D. (2008). Presupuesto General. Revista Fiscal de Derecho Penal.

OCDE. Mejores políticas para una vida mejor, recuperado el 18 de julio de 2015 http://www.oecd.org/centrodemexico/laocde/.

Parada, R. (2008). Derecho Administrativo. Madrid: Ediciones Juridicas y Sociales S.A.

Peña Gonzalez, E. (2007). Instuciones Presupuestales en Colombia. Universidad del Rosario.

Pérez, D (2012). Estrategia nacional de cooperacion internacional 2012-2014. Bogotá: Imprenta Nacional.

Pierri, G. G. (2009). Nuevo contexto de la Cooperacion Internacional. lsegib y Oea. España.

Pino Ricci, J. ( 2005). El Régimen Jurídico de los contratos estatales. Bogotá: Universidad Externado de Colombia.

Ramirez, H. (2009). Finanzas Públicas. Bogotá: Universidad Libre.

Ramos Acevedo, J. (2012). Contratacion estatal, Teoria General y Especial. Bogotá: Gustavo Ibañez. 
Ramos Venegas, M. R. (2009). Naturaleza jurídica de convenios de cooperación tecnica entre el estado colomabiano y una o varias organizaciones internacionales. Bogotá: Universidad del Rosario- Ensayos.

Real Academia Española. (s.f.). Recuperado el 06 de Mayo de 2015, de http://lema.rae.es/drae/srv/search?id=z5cojBb56DXX28TXuPM8

Restrepo, J. C (2005). Hacienda Pública. Bogotá: Externado de Colombia.

Reyes Yunis, L. (2007). Ley de Contratación Administrativa. Reforma a la Contratación Estatal . Bogota D.C.: Universidad del Rosario.

Rocuts, A., \& Barreiro, I. C. (s.f.). Sostenibilidad Portal. Obtenido de Catedra UNESCO de Sosteniblidad: Recuperado el 08 de junio de 2015 de http://portalsostenibilidad.upc.edu/detall_01.php?numapartat=2\&id=163\&numopcn=1

Rodriguez, L. (1994). Derecho Administrativo General y Colombiano. Bogotá: Temis.

Romero Pérez, J. E. (2002). Derecho Administrativo especial. Contratación Administrativa. San Jose.

Rosas, M., Fuentes, L., Quintero D. (2010). Lineamientos para modificaciones presupuestales. Bogotá: Departamento Nacional de Pleaneación.

Roseeau, A. (1990). El contrato social. Madrid: Espasa.

Rosero Melo, B. C. (2012). Generalidades en la Contratación Estatal. Bogota D.C.: Ediciones de la U.

Santamaria Pastor, J. (1975). La nulidad de pleno derecho de los actos administrativos. Madrid: Instituto de Estudios Administrativos.

Santofimio, Peña, Exposito, Matallana, Santos, Estrada... (2009). Estudios sobre la reforma del estatuto contractual.Bogotá: Universidad Externado de Colombia.

Santos Rodriguez, J. (2009). Consideraciones sobre los contratos y convenios adminitrativos. Revista Digital de Derecho Administrativo, 69 y ss.

Sayagués Laso, E. S. (1953). Tratado de derecho administrativo. Montevideo: Martin Bianchi Altuna.

Solano, J. E. (2010). Contratación administrativa. Bogotá: Ediciones doctrina y ley.

Suárez Beltrán, G. (2007). Gran reforma al estatuto de contratación publica en Colombia. Bogotá: Legis. 
Taborda, A. J. (2012). Debates sobre cooperación internacional para el desarrollo. Bogotá: Elacid.

Torres Vega, S. (2011). Convenios de cooperación internacional, Un mecanismos para la evasión de los principios de contratación estatal. Bogotá: Universidad Externado.

UNESCO. Construir la paz en la mente de los hombres y de las mujeres ,0020recuperado el 18 de julio de 2015 http://www.unesco.org/new/es/unesco/about-us/.

Valencia Restrepo, H. (2008). Derecho Internacional Público. Bogotá: Libreria Jurídica Comlibros.

Vega de Herrera, M., \& Ordoñez Maldonado, A. (1999). Contratación estatal: teoría práctica. Bogotá D.C. : Temis.

Vellas, P. (1967). Droit International Public. Paris. Instituciones Internacionales

Verocai, A. (2015). Organización de los Estados Americanos. Obtenido de Oficina de la OEA en Uruguay: http://www.oas.org/es/acerca/offices_detail.asp?sCode=uru

Vidal Diaz, E, Perez Sotelo R. (2012). Doctrina Contable complilada. Bogotá: Imprenta Nacional.

Vidal Perdomo, J. (1994). Nuevo regimen de la contratación Administrativa. Medellin: Dike.

Villegas Arbelaez, J. (2011). Carrera Administrativa y Concurso. Bogotá: Ibañez- Colección de Derecho Administrativo.

Welsch, G. (2005). Presupuestos, planeación y control. Mexico: Editorial.universidades.

Zambrano Olivera, E (2010). Contrataciones con Organismos Internacionales.

Perú.Contratando, 9-12.

Zambrano, M. A., \& Salazar, S. M. (2012). Aproximación a la cooperación internacional en seguridad alimentaria de Naciones Unidas en el Chocó, a partir de la Teoría postcolonialista. VLex.

Zea de Durán, M. (2002). Fundamentos juridicos de la Cooperación internacional en Colombia. Bogotá: Imprenta Nacional.

Zuleta González, M. M. (2004). La defensa del interes público en la contratación pública nos es dilema moral. Enento V foro "Etica Pública y Privada en la contratación estatal". Bogotá. 